\title{
Under the Park. Recent geophysical surveys at Verulamium (St Albans, Hertfordshire, UK)
}

\author{
Kris Lockyear and Ellen Shlasko
}

December 7, 2015

\begin{abstract}
This paper presents the preliminary results of the geophysical surveys - principally a large scale gradiometer survey — of Verulamium Park, St Albans, Hertfordshire, UK, under which lies approximately half of the Roman city. Verulamium was the third largest Roman city in the province of Britannia - covering some 81ha - and the largest which is currently available for survey. Approximately 65 ha lies under parkland or pasture. The 30ha available under the Park was the subject of a magnetometry survey in 2013-14, along with smaller areas of GPR, earth resistance and magnetic susceptibility. These surveys were undertaken as part of a community archaeology project funded by the AHRC. They have revealed a wealth of new information about the town and suggest zones into which the town may be divided.
\end{abstract}

Short title Recent geophysical surveys at Verulamium

Kris Lockyear Institute of Archaeology, University College London

Ellen Shlasko Independent researcher

Keywords gradiometer, GPR, Verulamium, Roman, town, Hertfordshire

Grant Arts and Humanities Research Council, Ref AH/K007602/1

Kris Lockyear

Institute of Archaeology, UCL

31-34 Gordon Square

London WC1H 0PY

noviodunum@hotmail.com

01582831946 


\section{Introduction}

The paper presents the results of a series of surveys in Verulamium Park, St Albans, during 2013-14 undertaken as part of the Arts and Humanities Research Council-funded project Sensing the Iron Age and Roman Past: geophysics and the landscape of Hertfordshire. This project trained a team of amateur geophysicists from a number of community archaeology groups in the region that has surveyed more than a dozen sites in Hertfordshire, Bedfordshire and Buckinghamshire. The team used a Foerster Ferex magnetometer, which mounts four sensors on a cart and allows relatively rapid survey of large areas (Fig. 1). The most ambitious of these surveys, was of the half of the Roman city of Verulamium that lies under parkland in St Albans (Fig. 2). An area of 30ha was surveyed between June 2013 and the end of January 2014. In addition to the magnetometry survey, members of the team undertook additional earth resistance, GPR and magnetic susceptibility surveys, mostly as part of a week-long geophysical survey course run by the project in July 2013, or subsequently as part of other training courses.

\section{Verulamium}

The city of Verulamium was the third largest town in the Roman province of Britannia, after London and Cirencester (Niblett 2001). It is currently the largest Roman town that is not buried beneath a modern city. Approximately half the town lies beneath Verulamium Park, land purchased by the city council in 1929 (in the foreground of Fig. 2), while the other half is pasture within the Gorhambury Estate, owned by the Earl of Verulam (the area beyond the road in Fig. 2).

The town had its origins in the late Iron Age, when a territorial oppidum developed in the area towards the end of the 1st century BC. This oppidum, like those at Colchester and Chichester, was a polyfocal settlement spread over some considerable area, especially on the SW edge of the river valley overlooking the site of the future Roman town, and with associated dyke systems (Niblett \& Thompson 2005, pp. 23-40). The principal pre-Roman feature within the later town was the 'Central Enclosure', which lies under the Roman forum-basilica complex, although this has only been seen in a small number of keyhole excavations (Niblett \& Thompson 2005, p. 32). 'Ditch 2' may constitute part of a larger enclosure to the north of the Central Enclosure, although the dating of it is uncertain (Niblett et al. 2006, 60-62).

After the Roman invasion, the town grew steadily around this central focus. A set of timber shops was constructed, originally thought to be of military construction (Frere 1972), although this interpretation has been challenged (Millett 1990). The earliest stone building appears to be on the 


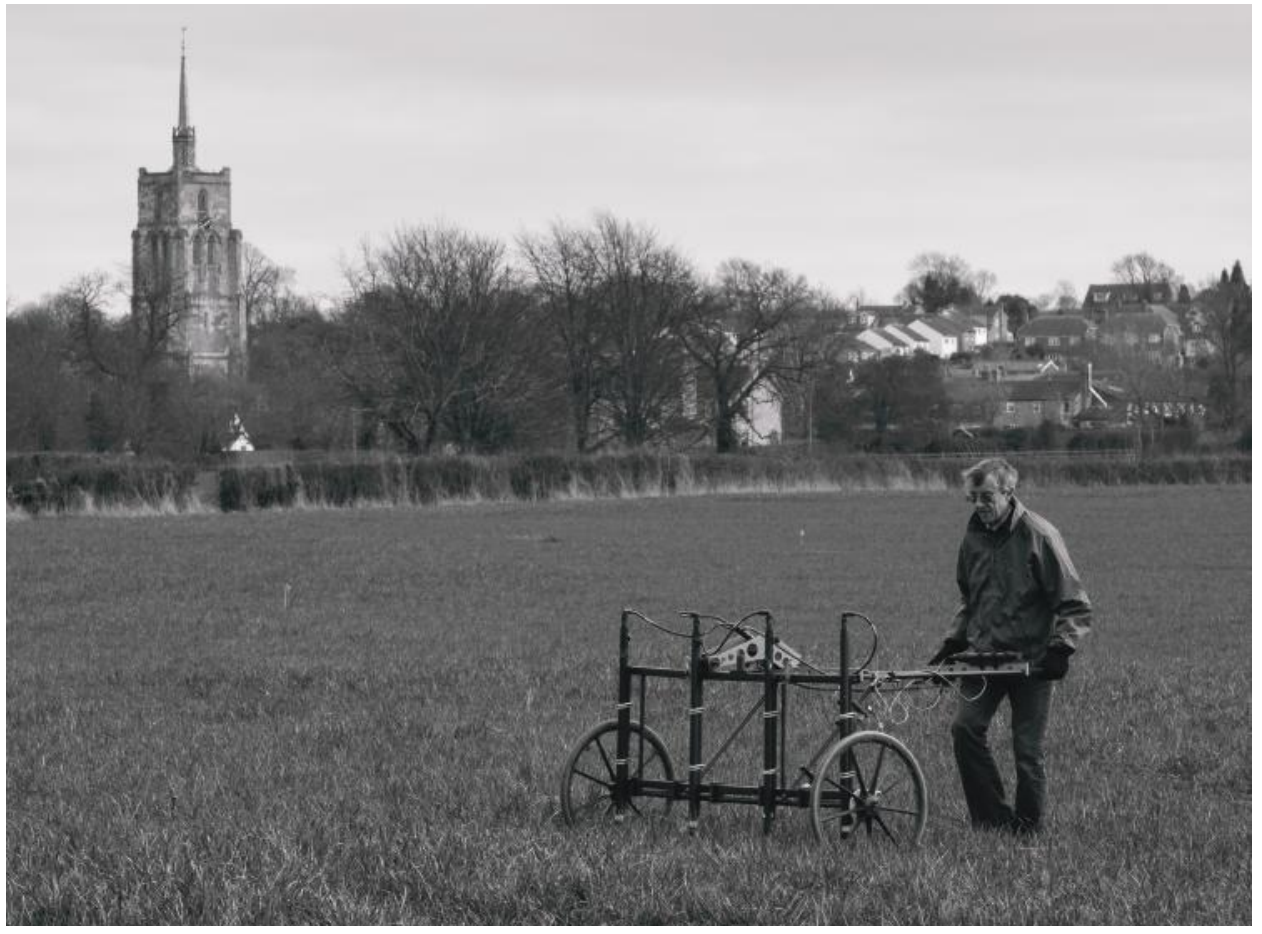

Figure 1: Jim West uses the Foerster Ferex magnetometer at Great Buttway, Ashwell End, Hertfordshire. 


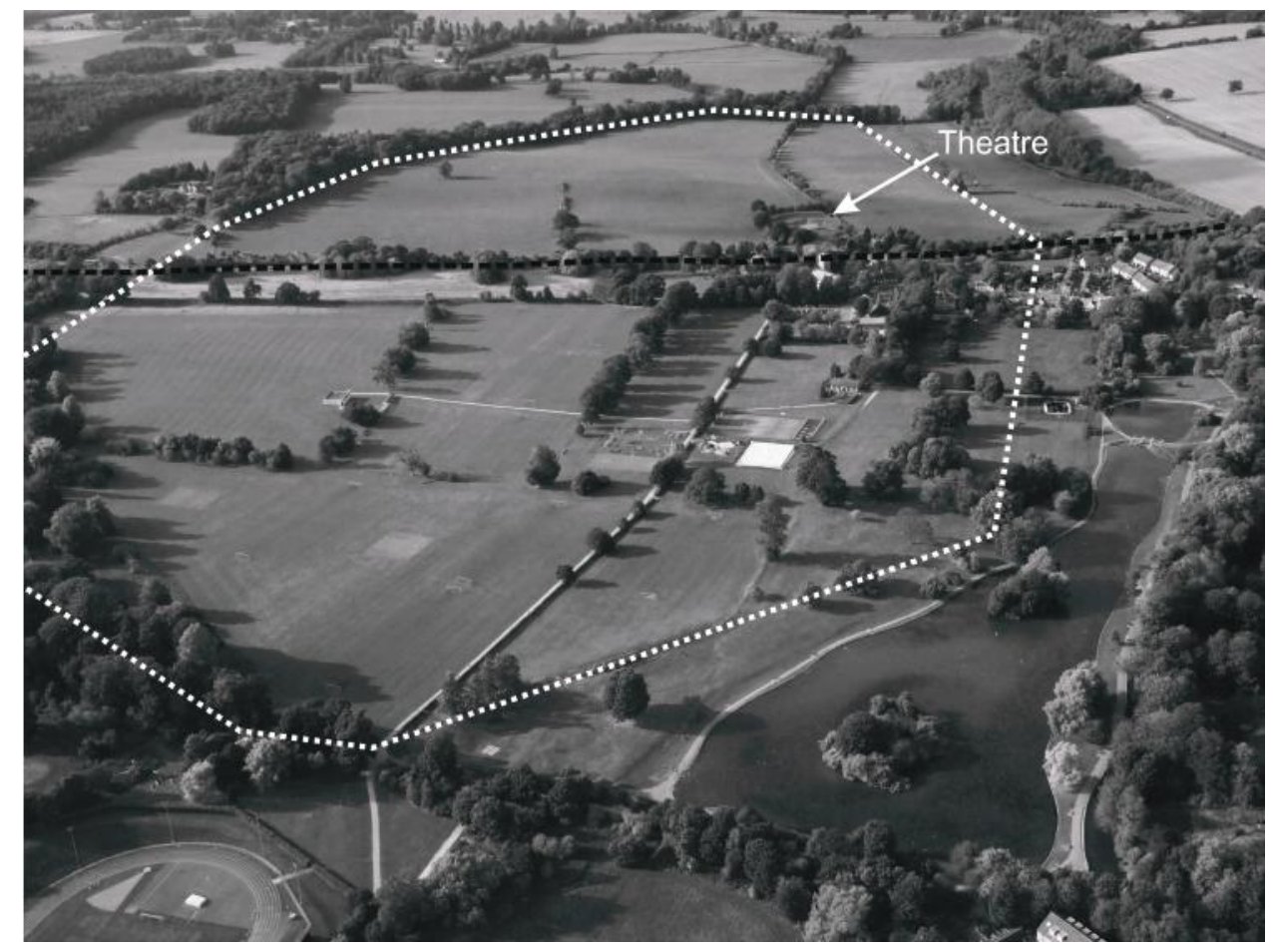

Figure 2: Aerial photograph of Verulamium taken looking north-west. The approximate line of the town wall is marked by the dotted white line. The Park lies in the foreground, the Gorhambury Estate in the background beyond the modern road marked with a black dashed line. Photograph (c) Jim West. 
site of the forum-basilica (Niblett 2001, p. 65). The structure on the site of the Six Bells public house was originally thought to be an early bath house (Niblett 2001, p. 65) although more recent work casts doubt on this (West 2015 , pp. 215-7). The early town was only about 10-12ha in extent.

In $\mathrm{AD} \mathrm{60/61} \mathrm{the} \mathrm{town} \mathrm{was} \mathrm{destroyed} \mathrm{during} \mathrm{the} \mathrm{Boudican} \mathrm{revolt.} \mathrm{This}$ event was recorded by Tacitus (Annales XIV, 33), although it is harder to identify archaeologically, in contrast to the Boudican destruction levels at Colchester and London (Niblett 2001, p. 67). It took about 15 years before construction began again in earnest. The inscription recording the building of the forum-basilica, dating to the period when Agricola was governor (AD 78-85) may refer to the earliest stone building mentioned above, or to a later rebuilding (Niblett 2001, pp. 73-77). At about this time, the '1955' ditch - so-called because Frere identified it in 1955 - was dug, marking the boundaries of the town in the late first and early second centuries (see Fig. 3). The town expanded rapidly but faced another set-back when a major fire destroyed many buildings in $c$. AD 155 (Niblett 1983-1986). After the fire, many buildings to the south of the forum were rebuilt as grand town houses in stone with mosaic floors and hypocausts.

During the third century, the town's boundary was extended to the line of the town walls indicated in Fig. 2. The exact date of this expansion is debated (Niblett \& Thompson 2005, pp. 71-75). What is also unclear is whether the entire area contained within the walls was extensively occupied, or whether there are areas that were fairly devoid of structures.

The nature of the town in the fourth century is a subject for much debate. The Wheelers described the town as bearing 'some resemblance to a bombarded city' (Wheeler \& Wheeler 1936, p. 28), the southern residential area as having 'decayed rapidly to slum-conditions' (p. 30) and the area around the forum as 'a sort of nucleated slum' (p. 31). This view of the city influenced a generation of thought about towns in Britain in the late Roman period. Frere (1983, pp. 20-25, 193-228), however, disputed this image of late Verulamium, citing the sequence in Insula XXVII, especially the late date for a substantial stone town house, as evidence for a vibrant city 'with a continued commitment to the classical tradition' (p. 24) into the fifth century. Reece (1980), whilst accepting Frere's dating, regarded the the buildings as merely 'the residences of the farmers of the local estates' (p. 88). Faulkner (2000) also supported this shorter chronology, stating that 'In Verulamium, after about 350, there were numerous grand old houses empty, boarded-up and derelict, their grounds rubbish-strewn, the streets outside pitted and ankle-deep in filth' (p. 126). More recently, the dating of the main stone structure has been challenged (Cosh \& Neal 2015; Neal 2003), with the main building phase being pushed back from $c$. AD 380 to the mid-second century, in line with other similar structures elsewhere in the town. Frere \& Witts (2011), however, rebutted Neal's arguments in the earlier of those two papers. Much of the dating relies on small numbers of 
coins, evidence that has been reviewed elsewhere (Lockyear 2012).

Our knowledge of the town derives largely from a number of large-scale excavations that took place in the period 1930-1965 (Frere 1972, 1983, 1984; Kenyon 1935; Lowther 1937; Wheeler \& Wheeler 1936). Although some further excavations have taken place inside the town subsequently (e.g., Niblett et al. 2006), the majority of excavation has been on threatened sites outside the town walls (see Fulford 2015), the line of which also marks the limits of the area protected as a Scheduled Ancient Monument (Fig. 2). Niblett \& Thompson (2005, Fig. 4.6, p. 51) provide a useful map of the excavated areas.

One of the earliest magnetometry surveys for archaeology was undertaken at Verulamium in 1959-1960 (Aitkin 1960, 1961) and successfully traced the line of the so-called ' 1955 ' ditch, the late first century boundary of the town (Niblett \& Thompson 2005, pp. 66-7). Coincidentally, the first feature detected in the new survey was also the '1955' ditch! Following this initial success, Aitkin conducted surveys at Verulam Hills Field (19634; Anthony 1968, p. 9) and on the King Harry Lane site (1965; Stead \& Rigby 1989, p. 1 and Fig. 2), although in both publications the surveys are only mentioned in passing. Other surveys have been undertaken, including one by Cardiff University in the late 1980s, sadly unreported (W. Manning, pers. comm.). The Ancient Monument Laboratory, part of English Heritage (now Historic England), conducted two surveys, one in 1993 in advance of tree planting along the southern and western edges of the Verulamium Park (Cole 1994), the second a series of transects in the north and western parts of the town, now part of the Gorhambury Estate (Linford 2000). Both these reports are only available as gray literature. Since 2000, some surveys have been commissioned by the District Archaeologist, e.g., the GPR survey and magnetometry surveys of the old tennis courts undertaken in 2010 prior to the building of the 2012 exercise area (Brien 2010), also only available as gray literature. As far as I am aware, the only published surveys are those by Aitkin in 1959-60.

Additional information about the town has come from by aerial photography and the plotting of parch marks. Niblett \& Thompson (2005) incorporate this information in their survey of the archaeology of the town, and especially in the maps at the back of the volume. An archive of these photographs is maintained by St Albans Museums.

\section{The new surveys}

The trend in recent years has been for geophysical surveys to cover increasingly larger areas at higher data densities. These surveys are now research projects in their own right, able to map the distribution of structures and features on a large settlement, or even a landscape. The Landscape Research 
Centre has mapped hundreds of hectares of the Vale of Pickering (Powlesland 2009, 2015) leading to a impressively detailed understanding of the development of the valley. Roman towns have also been the subject of such investigations, with the pioneering Wroxeter Hinterland Project leading the way (Buteux et al. 2000). At Wroxeter the entire available area of the Roman town was surveyed using magnetometry (Gaffney et al. 2000; White et al. 2013) as well as substantial areas using resistance survey (Dabas et al. 2000; Walker 2000) and GPR (Nishimura \& Goodman 2000). Of the four public towns in Roman Britain not covered by modern development, all apart from Verulamium have now been subjected to magnetometry survey of the entire available area. Silchester, and large areas of its environs, was surveyed by the Silchester Mapping Project between 2005 and 2010 (Creighton in press), and Caistor-by-Norwich has been mapped using a Caesium Vapour system (Bescoby et al. 2009; Bowden 2013; Bowden \& Bescoby 2008). A fifth settlement, Caerwent, was one of the smaller public towns at 18.5 ha, but only about half of its area is now available for survey. This has been partially surveyed as part of an episode of 'Time Team' (Wessex Archaeology 2009). Each of these surveys has contributed to debates surrounding these towns. For example, the image of Wroxeter as a 'garden city' ${ }^{1}$ has had to be substantially revised, and at Caistor-by-Norwich the idea that the town was a planned imposition on the Iceni after the Boudican revolt has now been rejected in favour of a more organic pattern of growth.

The current plan of Verulamium (Fig. 3) is a combination of evidence from the various excavations, with additional information from earlier geophysical surveys, aerial photographs and the mapping of parch marks in the park. Large areas of the town within the third century walls appear blank. Were these really 'empty', or simply areas where the occupation was of a type less likely to show on aerial photographs? Unsurprisingly, given the early date of many of the excavations, there are some problems. For example, the plan of the forum-basilica complex, so often reproduced in general text books on Roman Britain, incorporated errors such as the fact that the Victorian vicarage was wrongly located on early plans, and that it is a palimpsest not only of multiple phases, but also different excavations of varying quality (Niblett \& Thompson 2005, pp. 78-83). Locating some of the excavation trenches is equally difficult. For example, Frere's 'Site A' was located by measurements from the hedges and the 'surviving piece of city wall', and can thus only be roughly plotted (Frere 1983, p. 44, n. 4).

\footnotetext{
${ }^{1}$ The phrase 'garden city' for Wroxeter was used by Gaffney et al. (2000, p. 81). The plan of Wroxeter in Webster \& Stanley (1962-1963, Fig. 28) has an area labelled 'farm yards and buildings', and Lapper's reconstruction of the city shows large open areas (English Heritage Photo Library, Ref. J900034). A similar image is suggested by Alan Sorrell's reconstruction of Verulamium (reproduced in, for example, Thorold 2015, p. 15).
} 


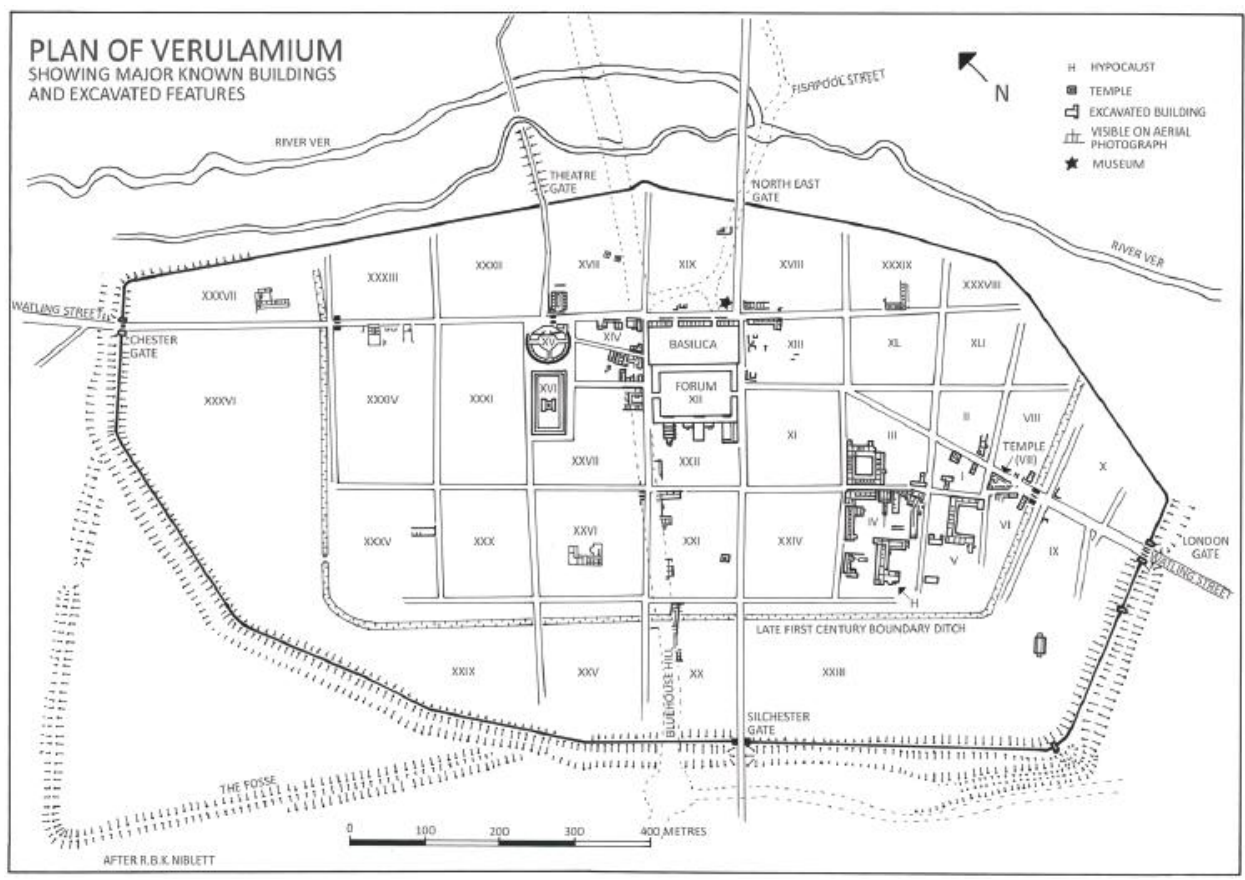

Figure 3: Composite plan of Verulamium. Drawn by Frances Saxton, reproduced with permission.

\section{Magnetometry survey}

It is against this background that the Sensing project chose Verulamium as one of its target sites. Having gained permission to work in the Park, survey began in late June 2013 and continued over the next seven months, usually once or twice a week. Approximately 45 survey days were completed, and an area of 29.7 ha was mapped, consisting of almost six million data points. Fig. 4 shows the overall results.

The data were processed in TerraSurveyor. The data processing steps were:

1. Export the Foerster FDL files as text tables and import them to TerraSurveyor.

2. Move any partial grid squares to their correct position within a $40 \mathrm{x} 40 \mathrm{~m}$ square if necessary.

3. Within a partial grid square, or small group of grid squares, mask any areas of 'fake' data and replace them with dummy values.

4. Construct the overall composite.

5. Destripe the data using zero median traverse with the minimum/maximum values set to $-10 / 10 \mathrm{nT}$. 


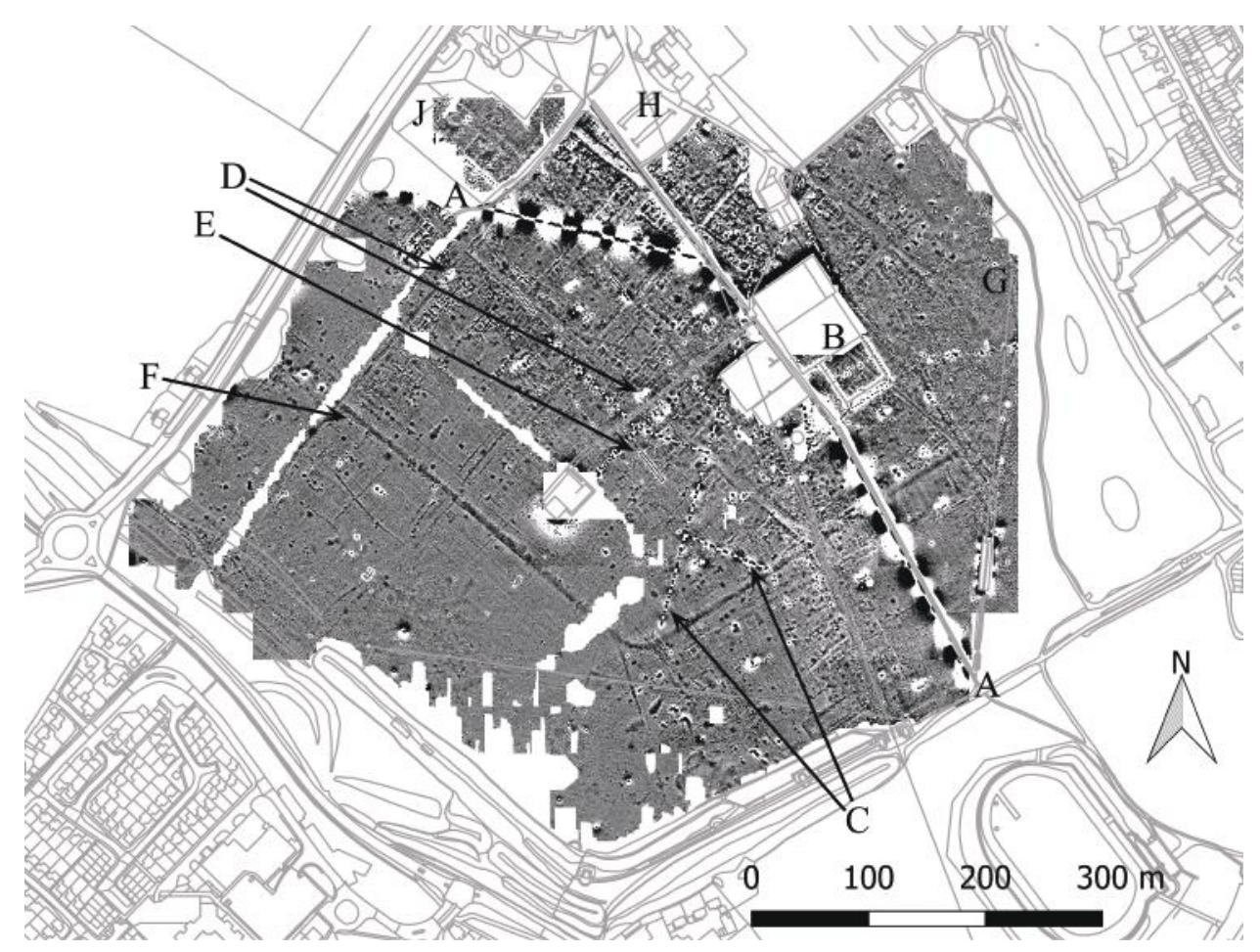

Figure 4: The magnetometry survey of Verulamium Park. The display range is $\pm 9 \mathrm{nT}$. Base map data (C) Crown Copyright and Database Right 2015, Ordnance Survey (Digimap Licence). 
6. Double the values on the y-axis via interpolation.

7. Run a low-pass filter with a $7 \times 3$ window.

8. Clip the image display, usually to $\pm 9 \mathrm{nT}$.

In a small number of cases where there was a complete break through the middle of the grid square, e.g., a hedge line, and thus the two halves had been surveyed separately, it was necessary to mask dummy data then destripe before performing step 2. For the purposes of presentation, the resulting composite image was then exported as a .png file for importing to Google Earth, or as a . tif file for inclusion in the QGIS project set up to analyse the results. When examining individual anomalies, it is possible in TerraSurveyor to look at the magnetic profile across the anomaly. Ferrous 'noise' regularly has a range of over $200 \mathrm{nT}$, whereas most archaeological features have a range much less than that, often less than $20 \mathrm{nT}$. The exceptions from this survey are the pottery kilns, which will be discussed further below.

The overall survey results (Fig. 4) showed a number of modern ferrous items in stark black and white. The large linear anomaly (A) that runs across the entire park is a 12 inch gas main constructed in 1951-2. The pipe has completely masked any archaeological features over a width of $30 \mathrm{~m}$. The white square with black dots (B) is where an iron fence has been cut down. There are numerous smaller pipes (C marks just two of these), goal posts (D marks some examples) and concrete cricket practice pitches (E marks an example). Despite all the modern interference, archaeological features showed quite clearly. At this scale, the most obvious feature was the '1955' ditch (F) running around the SW and SE sides of the town. General areas were also discernable. To the SW, outside the line of the ' 1955 ' ditch, the plot was very 'quiet'; there are anomalies, but not in the profusion and strength seen elsewhere. In the centre of the town, around the modern car park $(\mathrm{H})$, the results were very busy with a multitude of strong signals. The somewhat fuzzy results from the forum/basilica complex $(\mathrm{J})$ were the result of the excavations that took place there. The archaeology in the eastern side of the town was masked by upcast from the building of the lake in 1931 $(\mathrm{G})$. The SE part of the town between the '1955' ditch and the later town walls, which lie within the belt of trees to the south, was again quite busy. Is this evidence of the zonation claimed for Wroxeter (Gaffney et al. 2000, p. 98)?

A detailed feature-by-feature description of the results of this survey will be the subject of a future publication, when the survey of the entire town is complete. In this paper we have chosen a range of themes to discuss in detail. These are presented below. The ultimate aim of the surveys is to understand the structure of the town, and the themes chosen are those where the magnetometry data can make a significant contribution towards that aim. 


\begin{tabular}{|c|c|c|c|c|}
\hline Srvy no. & size $(m)$ & $\begin{array}{l}\text { transect } \\
\text { spacing }\end{array}$ & surveyor & location/reason \\
\hline 1 & $60 \times 40$ & $0.5 \mathrm{~m}$ & $\mathrm{RP}$ & training area \\
\hline 2 & $40 \times 40$ & $0.5 \mathrm{~m}$ & $\mathrm{RP}$ & $\begin{array}{l}\text { over rectangular mag. } \\
\text { anomaly }\end{array}$ \\
\hline 3 & $40 \times 50$ & $0.5 \mathrm{~m}$ & $\mathrm{RP}$ & $\begin{array}{l}\text { UCL training, over stone } \\
\text { building }\end{array}$ \\
\hline 4 & $40 \times 40$ & $0.5 \mathrm{~m}$ & $\mathrm{RP}$ & $\begin{array}{l}\text { UCL training, over stone } \\
\text { building }\end{array}$ \\
\hline 5 & $60 \times 40$ & $1.0 \mathrm{~m}$ & $\mathrm{LC}$ & training area \\
\hline 6 & $60 \times 40$ & $1.0 \mathrm{~m}$ & $\mathrm{LC}$ & training area \\
\hline 7 & $83 \times 37$ & $1.0 \mathrm{~m}$ & $\mathrm{LC}$ & forum \\
\hline 8 & $80 \times 30$ & $1.0 \mathrm{~m}$ & $\mathrm{LC}$ & possible bath house \\
\hline 9 & $60 \times 42$ & $1.0 \mathrm{~m}$ & $\mathrm{LC}$ & $\begin{array}{l}\text { possible bath house, Watling } \\
\text { Street }\end{array}$ \\
\hline 10 & $12 \times 15$ & $1.0 \mathrm{~m}$ & $\mathrm{LC}$ & forum \\
\hline 11 & $12 \times 16$ & $1.0 \mathrm{~m}$ & $\mathrm{LC}$ & churchyard/forum \\
\hline 12 & $30 \times 25$ & $0.5 \mathrm{~m}$ & $\mathrm{LC}$ & buildings in Insula XXXIX \\
\hline
\end{tabular}

Table 1: Details of the GPR surveys.

\section{Ground Penetrating Radar survey}

In addition to the comprehensive magnetometry survey, some smaller areas were subject to other techniques.

A total of twelve blocks have been surveyed so far using GPR: eight by Lawrence Conyers using a GSSI SIR 3000 with a $400 \mathrm{MHz}$ antenna, and four by Ralph Potter using a Malå X3M using a $500 \mathrm{MHz}$ antenna. The details of each survey are given in Table 1, and the locations in Figure 5. In the case of surveys processed by the author and Conyers, the package GPR Process was used to create the data for the time-slices, which were subsequently mapped in Surfer. The images kindly provided by Mike Langton were processed using Reflex-W.

The GPR surveys proved very successful at detecting buried architecture and greatly enhanced the results obtained by the magnetometer surveys. The results will be discussed in relation to specific features below.

\section{Resistance survey}

All the resistance surveys at Verulamium used the common 'twin probe' array with a $0.5 \mathrm{~m}$ separation between the mobile probes. Six separate areas were subjected to resistance survey (Table 2). The locations are shown in Figure 6 . The resistance surveys were processed using TerraSurveyor. The 


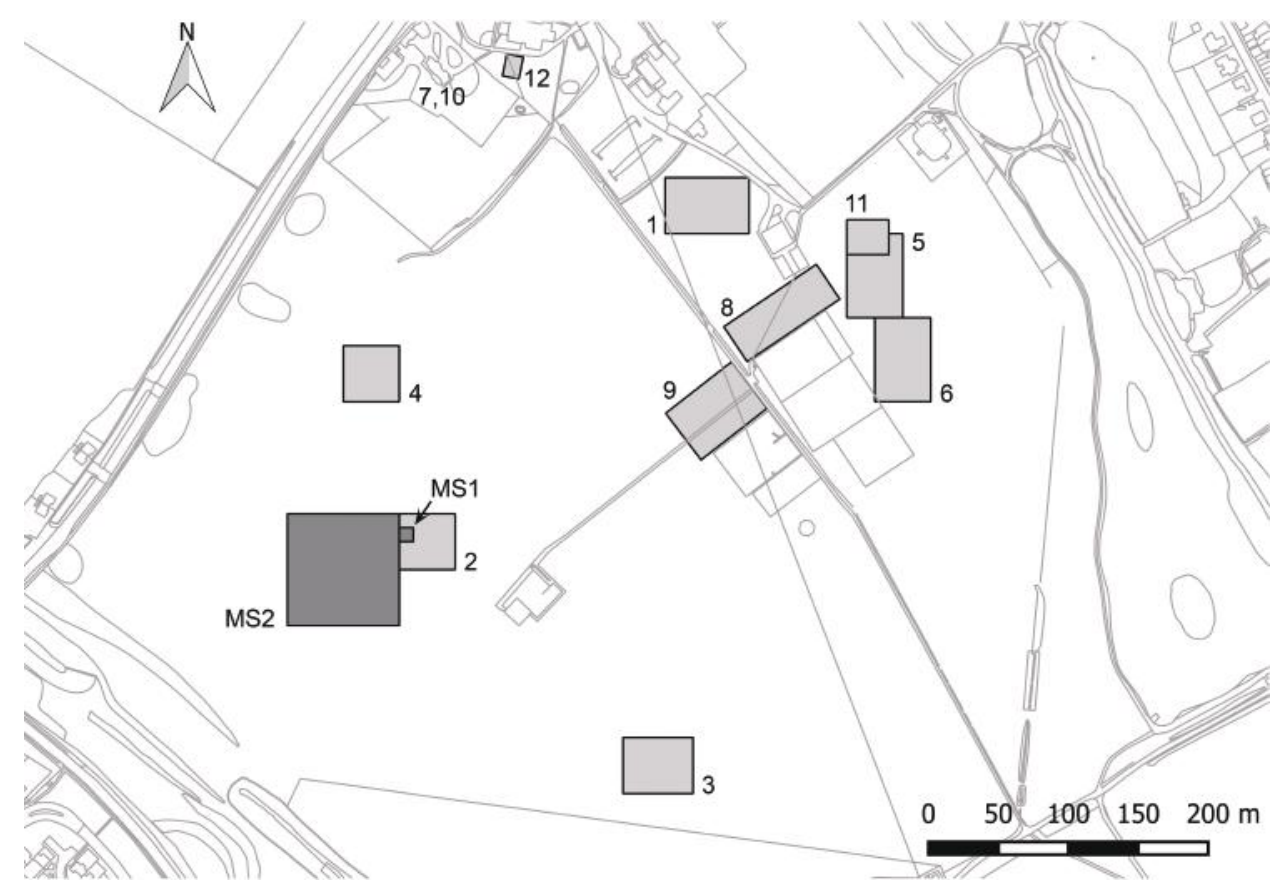

Figure 5: Location of the GPR and magnetic susceptibility surveys. Base mapping: (c) Crown Copyright/database right 2015. An Ordnance Survey/EDINA supplied service. 


\begin{tabular}{|c|c|c|c|c|}
\hline Survey no. & size $(\mathrm{m})$ & $\begin{array}{l}\text { data } \\
\text { density }\end{array}$ & surveyor & location/reason \\
\hline 1 & $20 \times 20$ & $1 / \mathrm{m}^{2}$ & $\begin{array}{l}\text { Bill Martin/ } \\
\text { Roger Miles }\end{array}$ & training area \\
\hline 2 & $20 \times 20$ & $4 / \mathrm{m}^{2}$ & course & $\begin{array}{l}\text { over rectangular mag. } \\
\text { anomaly }\end{array}$ \\
\hline 3 & $20 \times 40$ & $1 / \mathrm{m}^{2}$ & course & over ' 1955 ' ditch \\
\hline 4 & $60 \times 40$ & $4 / \mathrm{m}^{2}$ & CAGG & $\begin{array}{l}\text { over rectangular mag. } \\
\text { anomaly }\end{array}$ \\
\hline 5 & $20 \times 20$ & $4 / \mathrm{m}^{2}$ & CAGG & over stone buildings \\
\hline 6 & $40 \times 20$ & $4 / \mathrm{m}^{2}$ & CAGG & $\begin{array}{l}\text { UCL training, over stone } \\
\text { buildings }\end{array}$ \\
\hline
\end{tabular}

Table 2: Details of the resistance surveys.

\begin{tabular}{lrrll}
\hline Survey no. & size $(\mathrm{m})$ & $\begin{array}{l}\text { data } \\
\text { density }\end{array}$ & surveyor & location/reason \\
\hline 1 & $10 \times 10$ & $4 / \mathrm{m}^{2}$ & Rinita Dalan & $\begin{array}{l}\text { training area/ } \\
\text { rectangular mag. anomaly } \\
\text { training area/ } \\
2\end{array}$ \\
$80 \times 80$ & $1 / 4 \mathrm{~m}^{2}$ & Rinita Dalan & '1955' ditch \\
\hline
\end{tabular}

Table 3: Details of the surface magnetic susceptibility surveys.

details of the processing varied slightly between areas but usually consisted of edge-matching, followed by de-spiking and clipping. To produce the final images, the data density was doubled by interpolation and then a $3 \times 3$ lowpass filter applied. The results from using a high-pass filter were examined, but are not presented here.

The initial survey (1), undertaken by Bill Martin and Roger Miles (SAHAAS), showed Street 13 running SE-NW through the grid square and the extensive robbing of the road towards the north. Survey 3 clearly detected the ' 1955 ' ditch. The resistance surveys, although showing interpretable features, are generally proving less useful than the magnetometer and GPR surveys largely because the slow speed of the technique has led to relatively small areas being surveyed.

\section{Magnetic susceptibility survey}

Two area surveys were supervised by Rinita Dalan during the course in 2013 (Table 3). Both surveys were undertaken using a Bartington MS2 meter and the D-loop, which measures the magnetic susceptibility of the top $100 \mathrm{~mm}$ of soil. The results will be discussed below. The locations are 


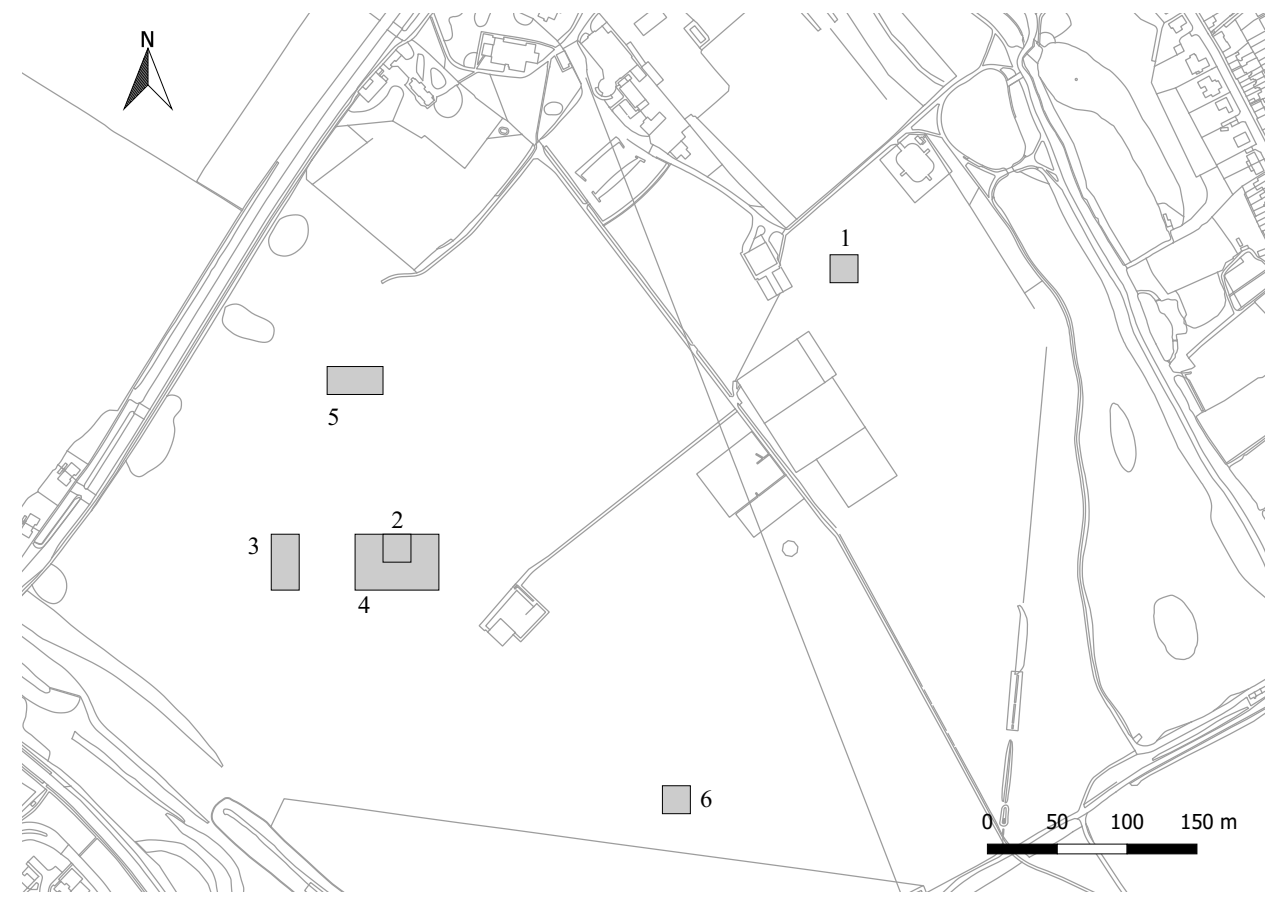

Figure 6: Location of the resistance surveys. Base mapping: (C) Crown Copyright/database right 2015. An Ordnance Survey/EDINA supplied service. 


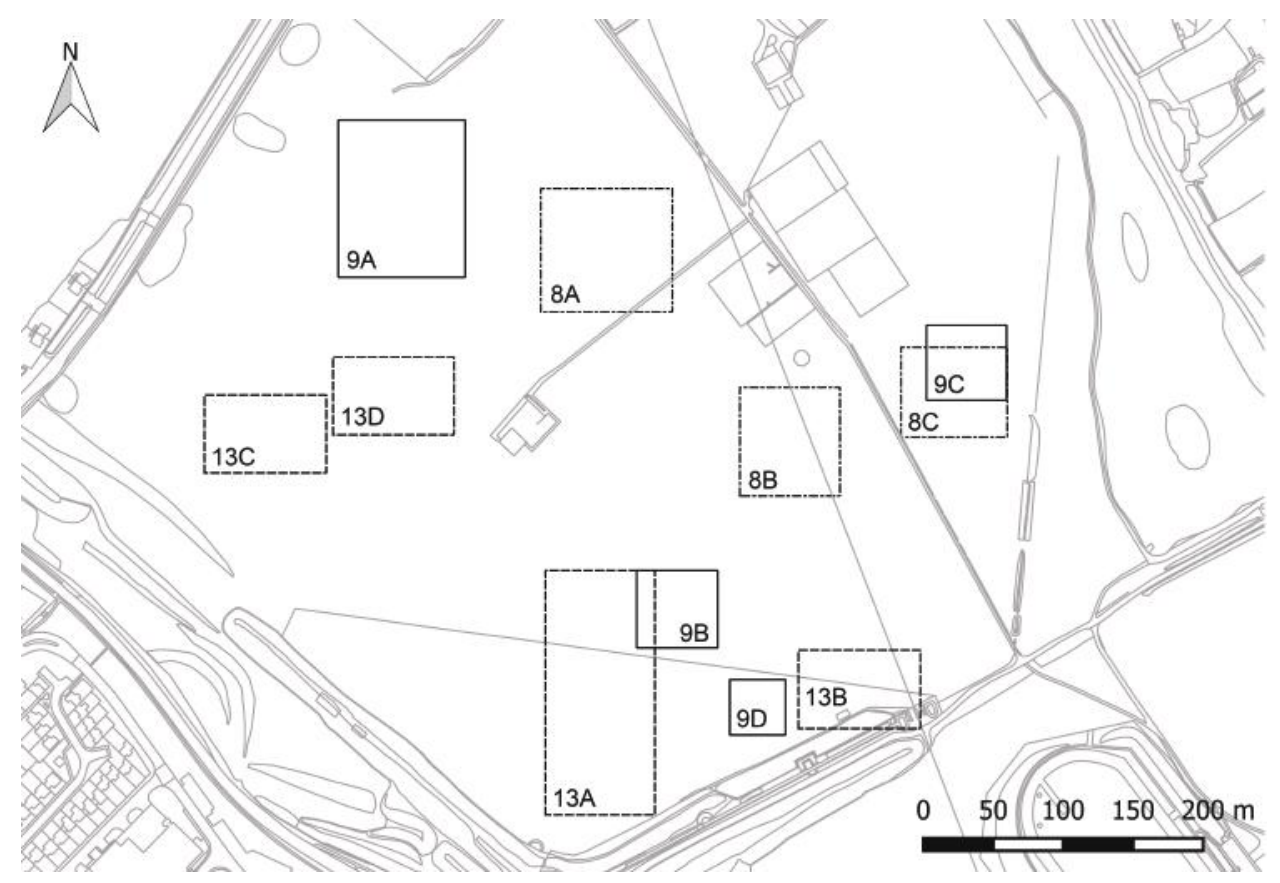

Figure 7: Location of details shown in Figures 8, 9 and 13 (labels refer to the figure numbers). Base mapping: (c) Crown Copyright/database right 2015. An Ordnance Survey/EDINA supplied service.

shown in Figure 5. The data were processed by Dalan, who corrected for drift and removed anomalous readings caused by surface iron. The contour plots were created in Surfer, using the nearest-neighbour algorithm. Downhole magnetic susceptibility soundings proved largely impossible, due to the extremely stony nature of the deposits.

\section{The results}

In the following discussion, extracts from the overall magnetic survey are provided. The location of each of these extracts is given in Fig 7 .

\section{Previously excavated areas}

As noted above, Verulamium has been subject to a number of excavations, those by Wheeler \& Wheeler (1936) and Frere $(1972,1983,1984)$ being particularly extensive. The Wheelers' excavations took place within what is now Verulamium Park and thus lie within the area surveyed to date. An important question when interpreting the results, is what impact the previous excavations have had on the magnetometry survey? How the excavations appear in the magnetic results, however, varied greatly from one area to 

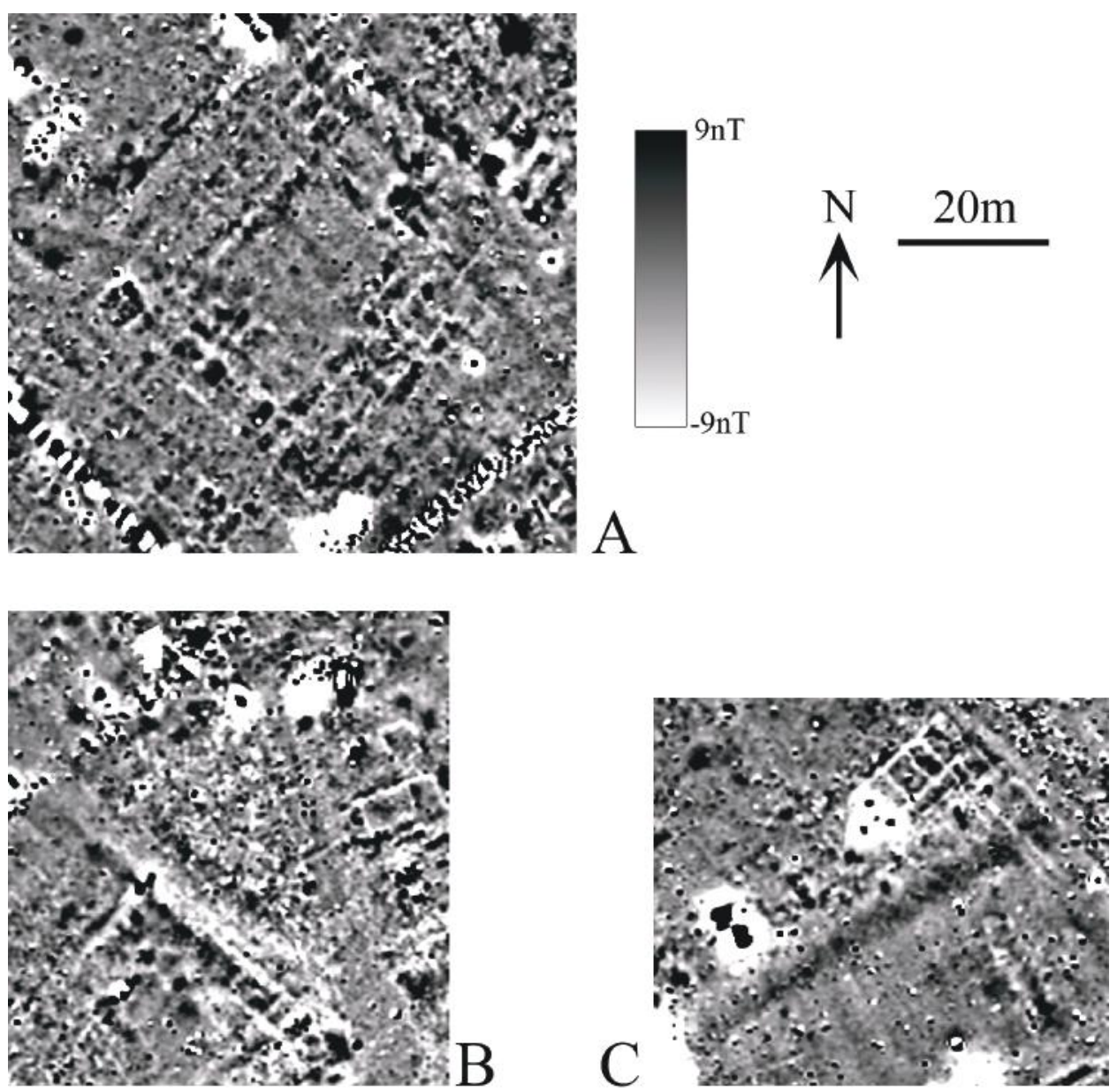

Figure 8: Magnetometry results over excavated areas (see text for details). A: Building III.2; B: the Triangular Temple; C: the '1955' ditch. The location of the details is given in Fig. 7 . 
the next. Comparing two of the structures excavated by the Wheelers illustrate this. Building III. $2^{2}$ (Fig. 8A), interpreted by the Wheelers as a large courtyard house, later suggested to be a mansio (Niblett \& Thompson 2005 , p. 159), showed moderately well on the survey. The walls appeared as having a low magnetic field (white) against the average to high magnetic field (mid-gray to black) of the surrounding deposits. The Triangular Temple (Fig. 8B), on the other hand, showed only as an area of noisy data bounded by three roads. What might explain this difference? Photographs of the temple excavation show that the Wheelers cleared the structure right down to the floors and surviving foundations. We hypothesised that the 'noise' seen in the results must be created by the randomly mixed backfill of the large excavation area. Comparing this to Building III.2, we concluded that the excavation of that structure must not have removed the deposits so completely. This was confirmed by a photograph of part of Building III.2 that showed a block of unexcavated deposit in the background (Wheeler \& Wheeler 1936, plate CI). Clearly, the excavation methods had an impact on the survey results.

Other excavation trenches were not detected at all. Figure 8C, shows a length of the '1955' ditch running as a dark band diagonally across the plot. Frere's 'Site A' trench across the ditch was somewhere in this area (Frere 1983, p. 44, n. 4), but cannot be identified in the data.

\section{Domestic buildings}

The majority of the known domestic buildings at Verulamium, especially those excavated by the Wheelers, were large, luxuriously appointed town houses. The excavated areas were, however, mainly concentrated towards the centre of the town (see Fig. 3). A number of questions can be posed. Firstly, can we see evidence of structures in the magnetic data? Secondly, if so, what factors may influence that visibility? Thirdly, does the magnetic data indicate zones or neighbourhoods within the town?

Earlier buildings at Verulamium were generally timber-framed with sleeper beams. Unless burnt down, like the famous row of shops in Insula XIV (Frere 1972, pp. 10-23), it was unlikely that magnetometry survey would detect them. In any case, it was also likely that early buildings would be covered with the remains of later structures, making their identification difficult. Later buildings, especially those constructed after the fire of $c$. AD 155, were often either half timbered or masonry structures. The foundations were usually trench-built with a base of gravel, rounded river cobbles or chalk nodules, on which were built flint and mortar footings. Tiles were used for turning corners and for bonding courses (Niblett \& Thompson 2005, p. 107). As flint is not magnetic, we would not normally be able to detect

\footnotetext{
${ }^{2}$ The buildings at Verulamium are numbered within insulae and thus III.2 is Insula III, building 2 .
} 

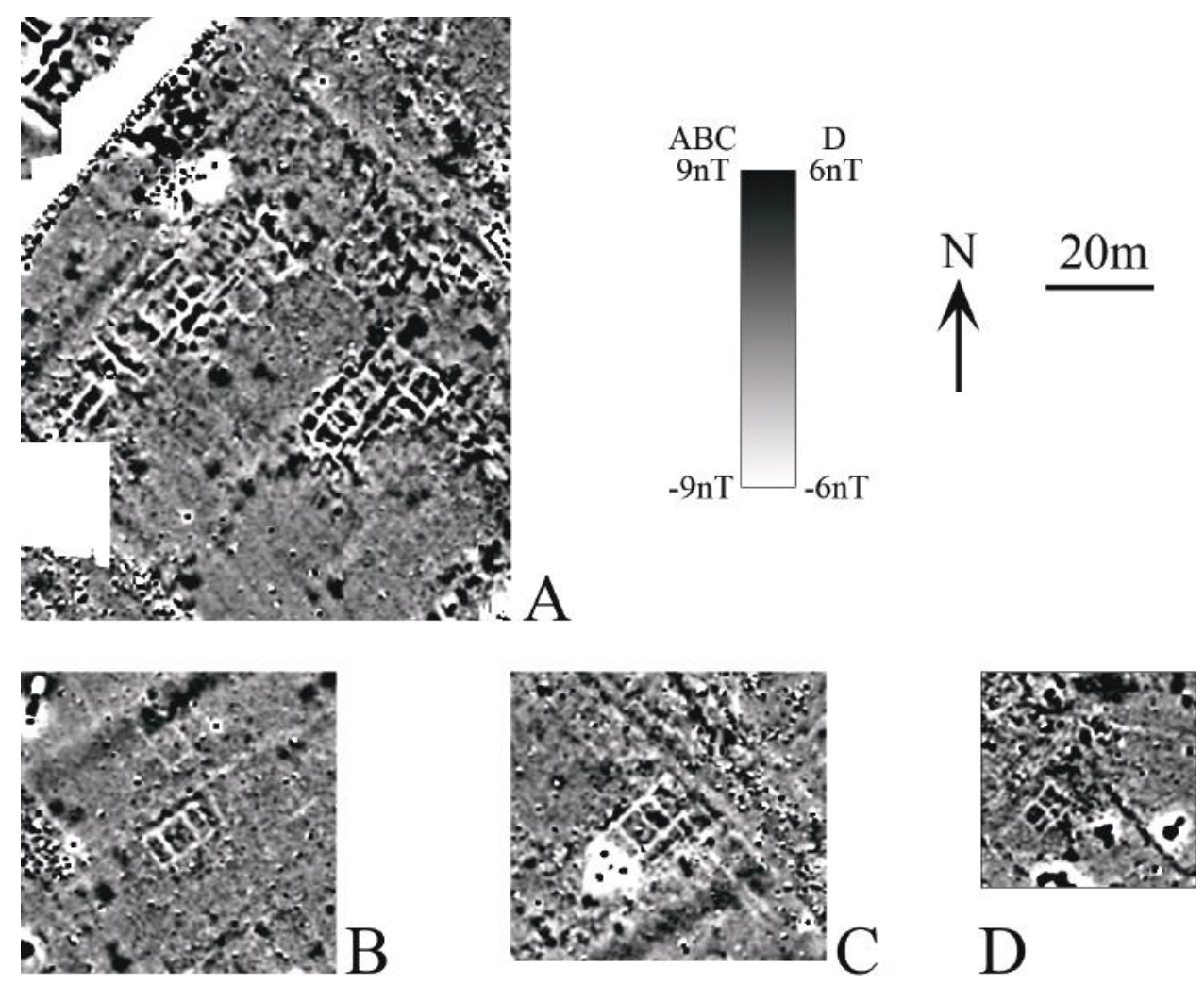

Figure 9: A selection of buildings detected at Verulamium by magnetometry. A: two structures within Insula XXIV; B: Insula VI; C: Insula VIII; D: Insula IX (see text for details). The location of the details is given in Fig. 7.

walls built of that material unless the footings cut through layers of more magnetic material (Gaffney \& Gator 2003, p. 37). This has indeed proved to be the case at Verulamium, where buildings can be seen as white lines in the plots, which indicate areas of low magnetism, within areas of more strongly magnetic material shown as dark gray or black.

Fig. 9 shows a selection of the detected buildings. At least two quite large structures, probably town houses, have been detected in the northern quadrant of Insula XXIV (Fig. 9A). These may be buildings XXIV.1 and XXIV.2 (Niblett \& Thompson 2005, Monuments 440 and 441, p. 331) known from aerial photographs, but their locations do not match very well. They were clearly large, well-appointed houses along the lines of those excavated to the south by the Wheelers, e.g., Buildings IV.7 or V.1 (Wheeler \& Wheeler 1936, pp. 102, 109-111, plates XXXIII and CXX). The building to the NW lay along the edge of the Silchester Road (street 18), which ran diagonally across the top-left corner of the image. There was a quiet area between the two main structures with a small number of large positive anomalies. These 
were quite large, up to $4 \mathrm{~m}$ across, and moderately-to-strongly magnetic with a range of between $12-24 \mathrm{nT}$. These could either be large rubbish pits or external hearths.

Fig. 9B shows a much more modest dwelling lying just outside the ' 1955 ' ditch, which ran diagonally across the top-left corner of the plot. This building consisted of three or four rooms and was approximately $11 \mathrm{~m}$ by $6 \mathrm{~m}$. Just to the north of this structure, a second one was seen partially overlying the ditch. Frere excavated two trenches across the ditch and suggested that it was backfilled in the middle decades of the second century (Niblett \& Thompson 2005, p. 67) giving us a terminus post quem for the building.

A building of intermediate size (Fig. 9C) lay on the eastern edge of the town just to the north of the line of the ' 1955 ' ditch. In plan, it resembled a winged corridor villa, although the western end of the building was masked by three strong magnetic anomalies caused by something ferrous. The building was more modest than the winged buildings listed by Niblett \& Thompson (2005, p. 114) although there are faint traces of what could be a range of rooms along the road.

The structure shown in Fig. 9D was only $9 \times 5 \mathrm{~m}$ in size, with perhaps four rooms. The structure was close to a number of pottery kilns and could be related to that industry. Of known buildings from the town, it was similar in plan, although more modest in size, to Building III.2B, which underlies the possible mansio noted above (Wheeler \& Wheeler 1936, p. 94 and plate XXVIII). It was thought III.2B was burnt in the Antonine fire.

We have to be wary, however, of treating these images as the complete picture of the structures and their surroundings. Three buildings have additionally been subjected to a GPR survey (Fig. 10-11). In all cases, additional features can be seen. Figure 10 compares two magnetometry plots with four time slices over the same area. In the case of Figure 10A, some of the buildings that showed in the magnetic data were hard to discern in the GPR data, and some were quite clear. The most likely explanation is that those foundations that are are hard to see in the GPR data have been robbed completely whereas those that showed clearly in both sets of data have surviving foundations. In addition, further rectangular buildings were seen to the SE of the main structure running NW-SE. This building lay in what was originally thought to be an open area between the two larger structures in Insula XXIV. The advantages of undertaking more than one type of geophysical survey are clear.

In Fig. 10B, the building that showed very clearly in the magnetic data had some additional detail added by the GPR data. In the 20-24ns time slice, another internal wall appears. The building that lies over the '1955' ditch showed very clearly in the GPR data, with an extra internal wall seen most clearly in the 24-28ns time slice. Interestingly, the ditch did not show at all, whereas the roads, especially Street 2 that runs between the two structures, showed clearly. 

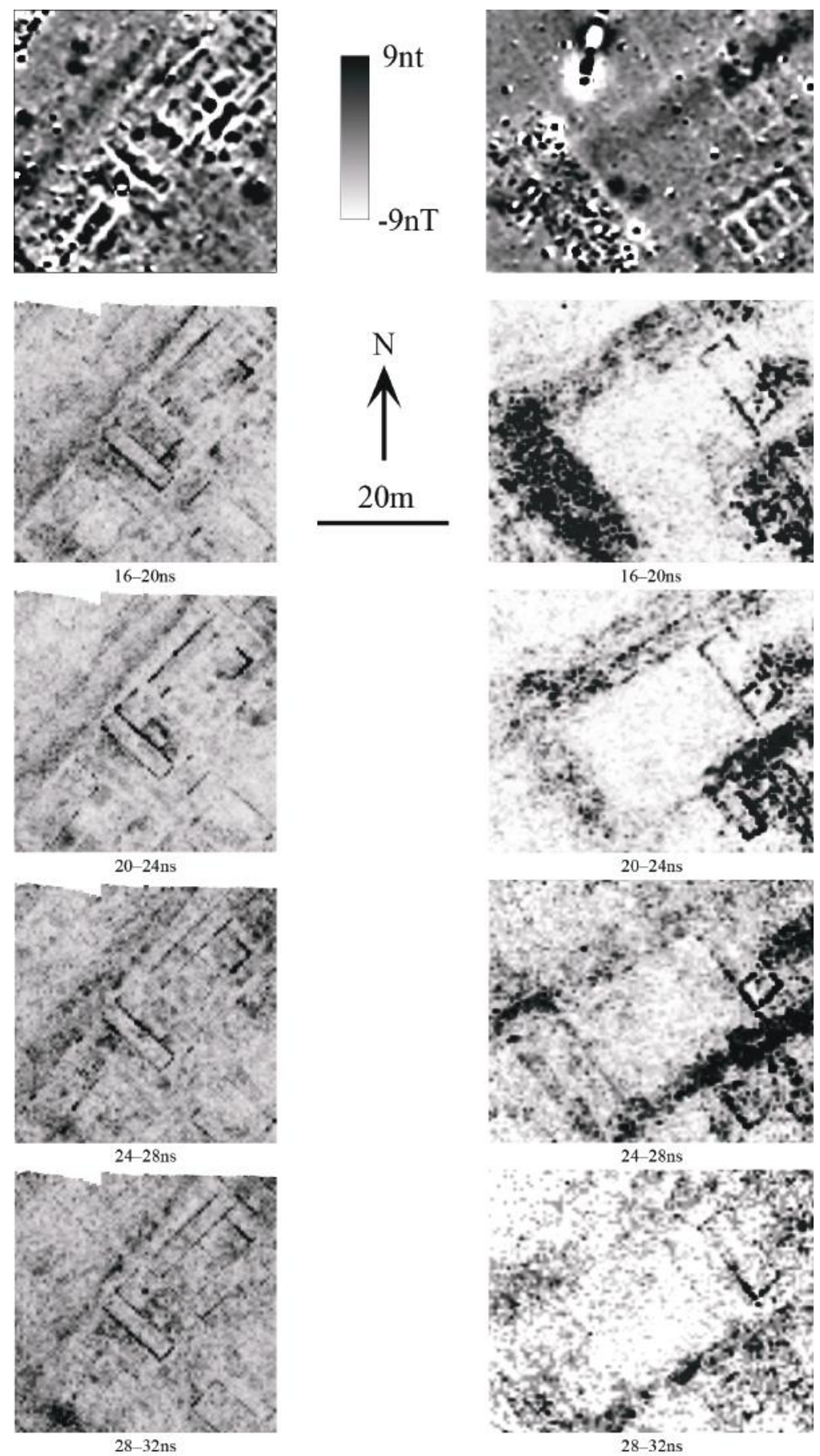

A

B

Figure 10: A comparison between the magnetometry plots and GPR timeslices. A: part of Insula XXIV and the Silchester Road (images courtesy of Mike Langton); B: part of Insula VI (see text for details). Both surveys were undertaken by Ralph Potter. For the location of the surveys, see Figure 5, surveys 4 and 3 . 

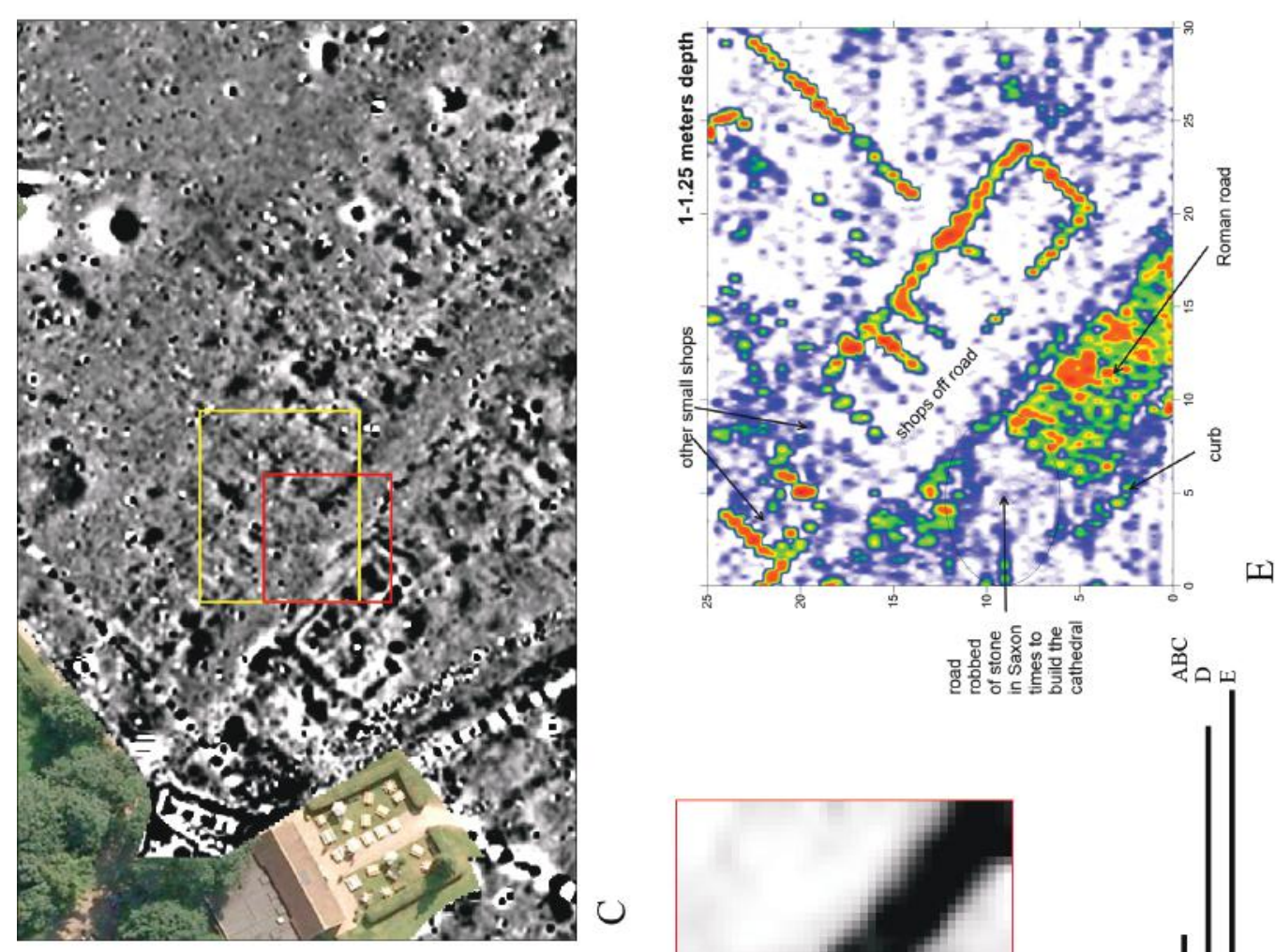

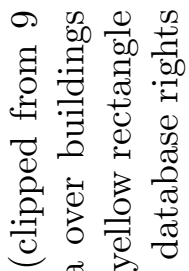

苞焉

苛

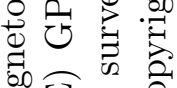

总国过

已

80

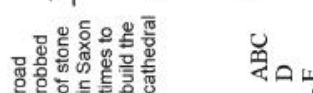

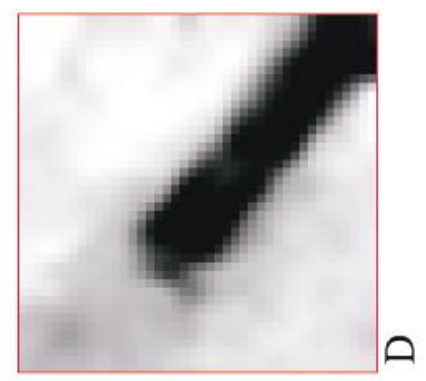

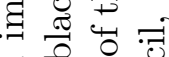

굴

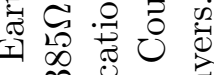

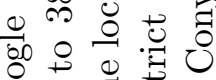
రण

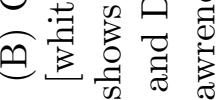

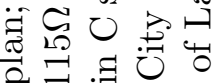

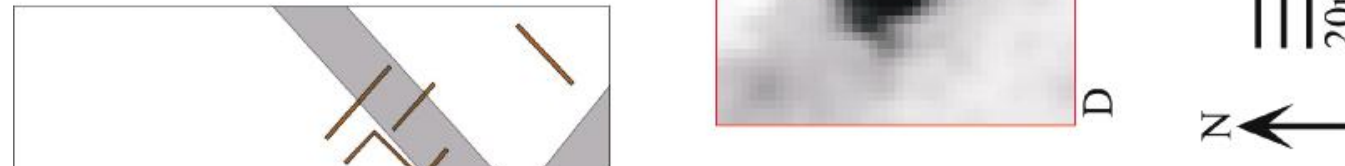

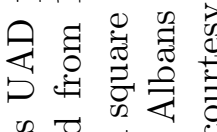

颉㤩范

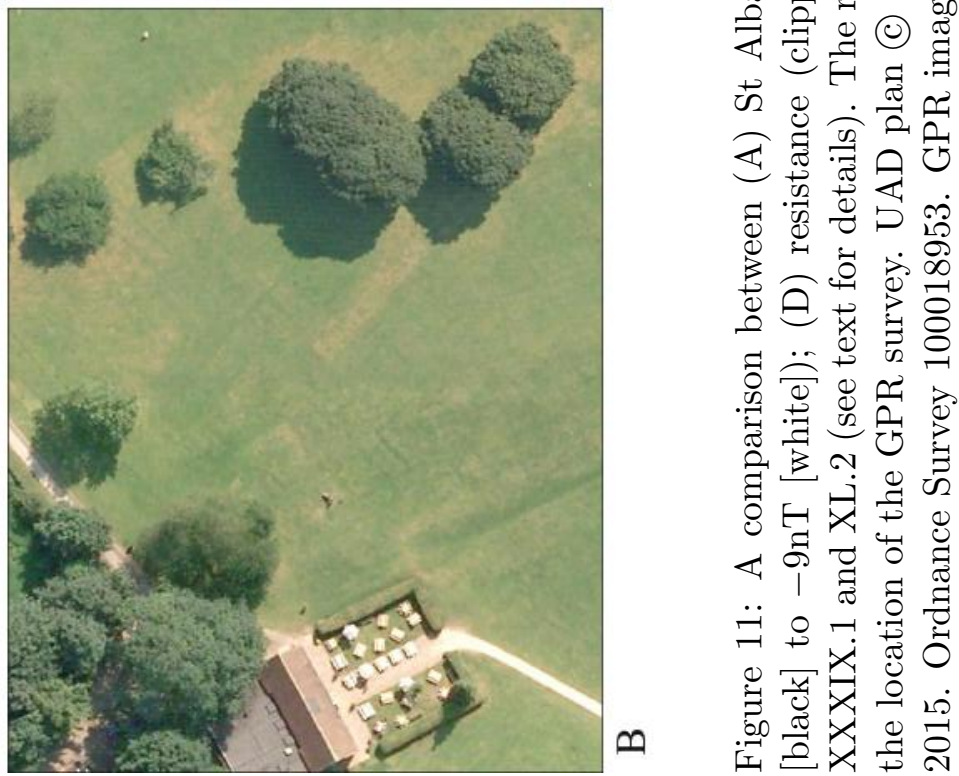


In Insulae XXXIX and XL, either side of Street 13, lay two stone buildings, which sometimes show as parch marks. Street 13 was robbed at one point, which again, often shows in the grass (e.g., the satellite imagery taken on 30 June 2009 available in Google Earth, see Fig. 11B). The grid of resistance data collected by Bill Martin and Roger Miles clearly showed the robbed road (Fig. 11D). The GPR data (E) collected by Lawrence Conyers also showed the robbed road as well as some buildings alongside it. The magnetometry data (B), however, does not show the building in Insula XXXIX at all, but does show the building just across the road in Insula XL. This maybe because of the distribution of Antonine fire debris (see below), some of which was recovered from the site of the cafe close to the building in Insula XL.

To return to our questions, we have been able to detect buildings, but the clarity of the images depends on the distribution of magnetically enhanced sediments and robbing. The larger structures were near the centre of the town, with more modest structures occurring towards the town boundaries.

\section{Kilns}

Moderate amounts of evidence have been gathered for the economic and industrial base of Verulamium, helpfully summarised by Niblett \& Thompson (2005, pp. 126-38). The magnetometry survey was able to contribute to our understanding of this industrial base, specifically as regards pottery production. The Verulamium pottery industry is well-known (Niblett 2001, pp. 102-3), and was one of the main pottery industries in the province in the late first and second centuries, manufacturing both mortaria (Tyers 1996, 132-4) and white wares (Tyers 1996, 199-201). The magnetometry survey by English Heritage detected some anomalies interpreted as kilns (Cole 1994) that correspond to those shown in Fig. 12D.

The new survey also detected a number of probable and possible kilns in the southern part of the town, of which a selection is presented in Fig. 12. The clearest kiln was the eastern one in Fig. 12D, with a clear chamber and flue, presumably similar to those excavated to the south of the town in 19634 (Anthony 1968, pp. 22-36). Two anomalies that looked like double-kilns (Fig. 12B-C) were probably successive replacements in the same location. Two groups of kilns (C-D) may represent individual workshops. The large positive anomaly in the middle of $\mathrm{C}$ could represent a quarry-pit filled with later rubbish, or perhaps a medieval/post-medieval chalk-pit. While some kilns were clear, other anomalies were more ambiguous, e.g., A and E. In the absence of excavation, was there any other evidence to support the suggestion that these are kilns? The range of $\mathrm{nT}$ values in Table 4 shows that A lay well within the range of probable kilns, whereas $\mathrm{E}$ had a range more than double the other anomalies. It is likely, therefore, that E reflected the presence of something ferrous and was not a kiln. The interpretation 


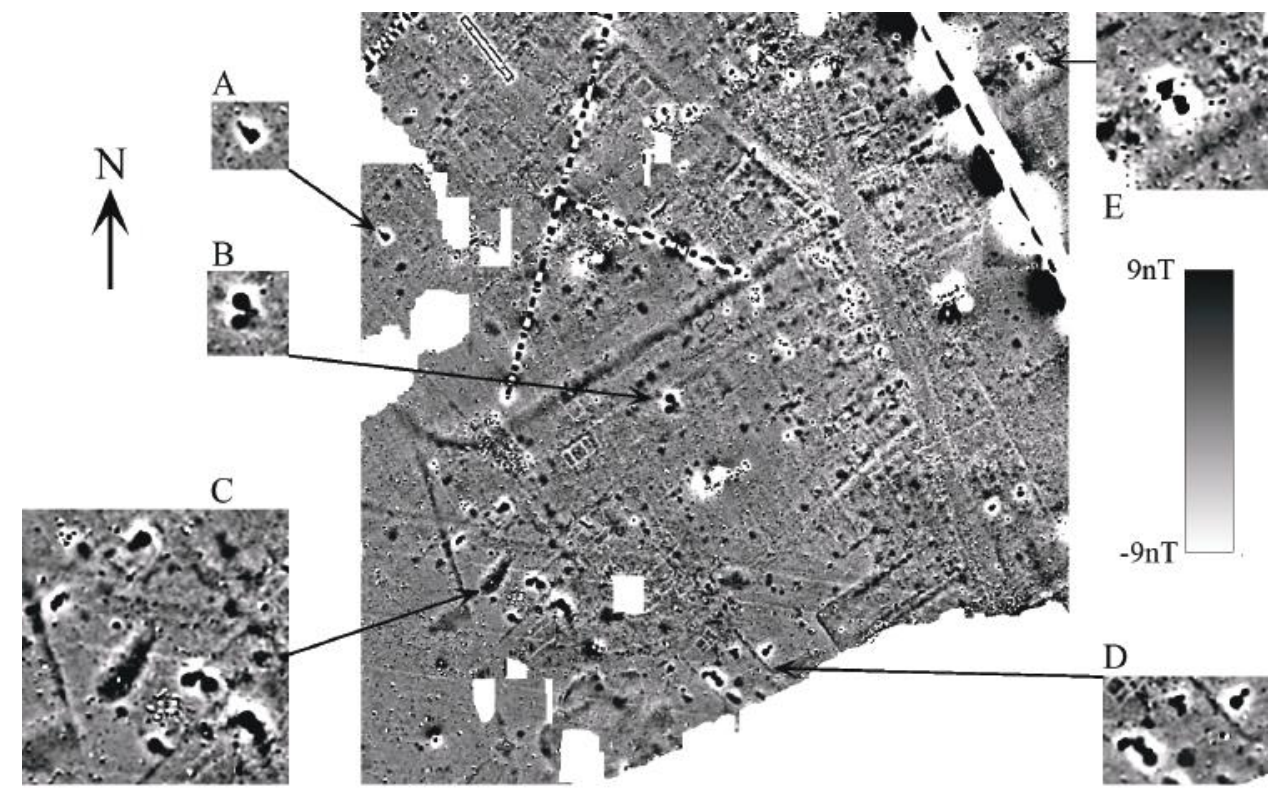

Figure 12: Probable and possible pottery kilns.

that anomaly A was a kiln was further supported by the fact it was close to Building V.3 (Wheeler \& Wheeler 1936, pp. 111-112), to the south of which was found Pit 6 , a feature that produced a number of saggers and wasters (Wheeler \& Wheeler 1936, pp. 186-90).

The majority of the known kilns at Verulamium came from the south of the town (Niblett \& Thompson 2005, Fig. 4.58), with the exception of one possible kiln in Insula XIII (Niblett et al. 2006, p. 92). This pattern was reinforced by the survey results, creating the impression that the southern part of the town outside the line of the '1955' ditch may have been a busy industrial area.

\section{Selected other features}

A number of other magnetic anomalies contribute towards our understanding of the town's layout. Fig. 13 contains a selection of these magnetic anomalies, some of which pose perhaps more questions than they answer. Fig. 13A shows a linear anomaly running from the corner of the ' 1955 ' ditch past the possible pottery workshop (Fig. 12C). It became very faint towards the south of the survey towards the 3rd century town walls. This linear anomaly, almost certainly a ditch, also formed a boundary between the very quiet area in the SW of the survey (cf. Fig. 4) and the busy area to the south of the '1955' ditch. As mentioned above, the '1955' ditch was sectioned twice by Frere in the southern part of the town (Frere 1983, pp. 44-9). 'Site M' lay just north of the hedge line, the unsurveyed area in Fig. 13A (Frere 


\begin{tabular}{llcc}
\hline kiln & $\min (\mathrm{nT})$ & $\max (\mathrm{nT})$ & range $(\mathrm{nT})$ \\
\hline $\mathrm{C} 3$ & -12.75 & 101.27 & 114.02 \\
$\mathrm{C} 2$ & -19.08 & 98.33 & 117.41 \\
$\mathrm{C} 4$ & -26.54 & 102.06 & 128.6 \\
$\mathrm{D} 2$ & -19.29 & 117.5 & 136.79 \\
$\mathrm{D} 3$ & -19.65 & 117.62 & 137.27 \\
$\mathrm{~A}$ & -14.03 & 130.4 & 144.43 \\
$\mathrm{C} 5$ & -27.09 & 123.23 & 150.32 \\
$\mathrm{~B}$ & -27.7 & 141.45 & 169.15 \\
$\mathrm{C} 1$ & -22.53 & 157.2 & 179.73 \\
$\mathrm{D} 1$ & -12.86 & 170.81 & 183.67 \\
$\mathrm{E}$ & -66.14 & 306.35 & 372.49 \\
\hline
\end{tabular}

Table 4: Minimum, maximum and the range of nanotesla values for possible kilns at Verulamium.
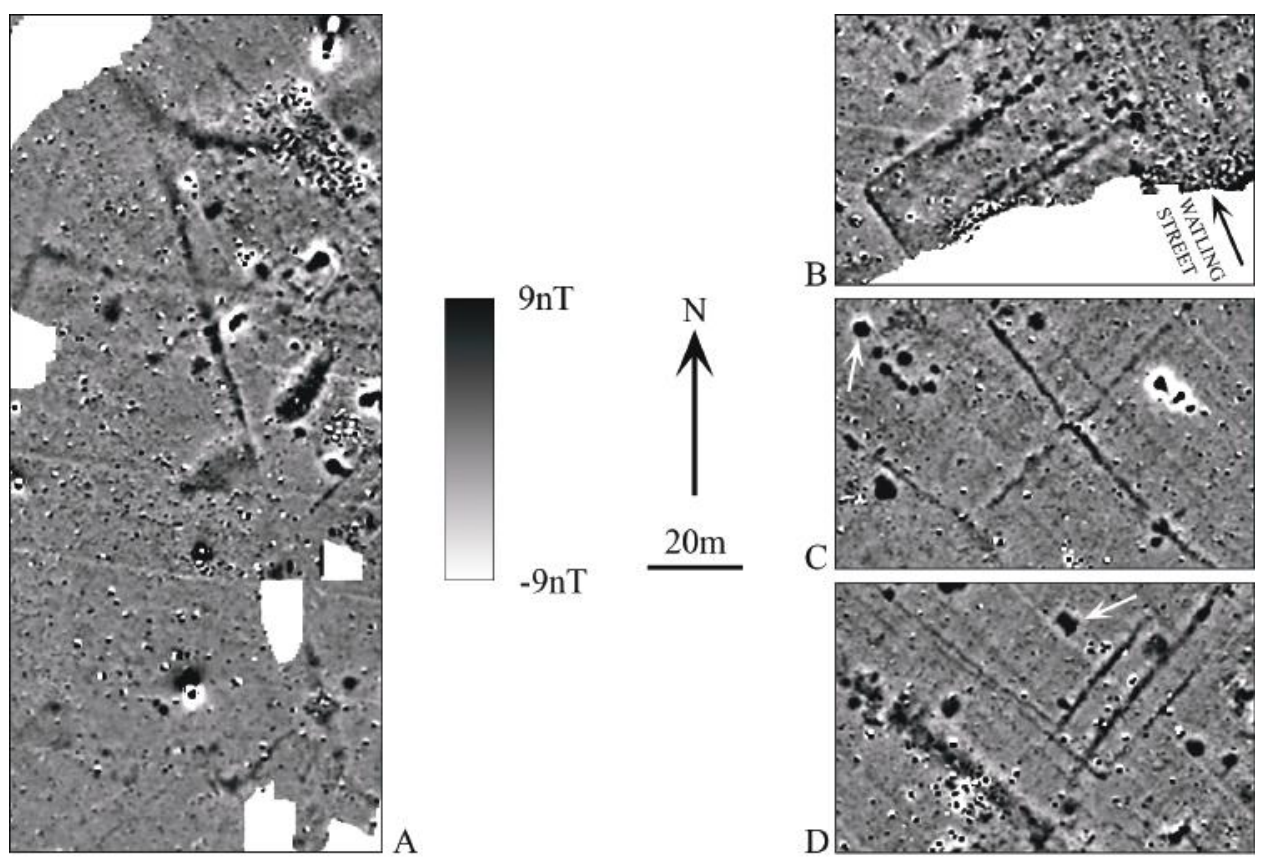

Figure 13: A selection of magnetic anomalies discussed further in the text. A: ditch joining ' 1955 ' ditch; B: enclosure near London Gate; C: anomalies in the 'quiet' western area'; D: rectangular anomaly just inside the '1955' ditch. The location of the details is given in Fig. 7. 
1983, p. 44, n. 5). Here, the stratigraphy suggested that the ditch was still 2m deep in AD 140-160 (Frere 1983, p. 48), and was not really levelled until AD 220. Given the dense settlement to the south of the '1955' ditch, could this new feature represent an expansion in the boundaries of the town that post-dates the Flavian '1955' ditch and was subsequently replaced by the later town walls to the south, which were built at some point in the $3 \mathrm{rd}$ century (Niblett \& Thompson 2005, pp. 72-3)?

Fig. 13B shows a linear anomaly that ran SSE-NNW for $17.5 \mathrm{~m}$ before turning a right angle and running at least $16 \mathrm{~m}$ to the ENE, and was perhaps traceable as a faint negative anomaly for another $14 \mathrm{~m}$. This linear anomaly may be the western and northern sides of an enclosure. It had values from -6.3 to $27.9 \mathrm{nT}$ on the western side, and -9.5 to $9.5 \mathrm{nT}$ on the northern. Just where the northern side faded, a marked line of anomalies, probably a row of pits, lay just to the south of it. These possible pits had values from -6.5 to $39.8 \mathrm{nT}$ in strength. Two further linear anomalies lay parallel with these 'pits' $13.5 \mathrm{~m}$ and $17 \mathrm{~m}$ to the SSE. South of this area was the bank of the town wall, and the eastern side was crossed by the line of Watling Street. Although superficially similar to the corner of a small Roman fort, the maximum width of the ditch was only $c .1 .6 \mathrm{~m}$ and the corner seems too tight. The only evidence that the anomalies described form part of one complex was their layout. Keith Fitzpatrick-Matthews (pers. comm.) suggested that an analogous complex may be found at Baldock represented by ditches A1 and A2 and pits A5-A11, A14-A18 (Stead \& Rigby 1986, p. 44-7, Figs. 4, 16 and 39A). The discussion does not offer, however, any interpretation of these features (Stead \& Rigby 1986, p. 86), although it has been suggested that it may be 'ritual'. The outer ditch did, however, seem to underly the bank behind the Roman wall and thus predates the wall's construction.

Fig. 13C lay outside the line of the '1955' ditch in the 'quiet' area of the survey. The linear anomalies found here are often seen in aerial photography and are undated. Niblett \& Thompson (2005, Plan 5) tentatively place them in the early 3rd century interpreting them as field/allotment boundaries but they could equally post-date the Roman town. Most of these anomalies had readings of between -4 and $10 \mathrm{nT}$. Given the lack of evidence for buildings, the large numbers of sub-circular anomalies in the 'quiet area' SW of the ' 1955 ' ditch was curious. Were these large pits, or perhaps external hearths to buildings we can not detect, as has been found elsewhere in the town? A sample of 12 of these anomalies from Fig. 13 showed that most had a range of $23.7-47.2 \mathrm{nT}$ whereas just one, indicated by an arrow, had a range of $65.5 \mathrm{nT}$, suggesting it represented a different type of feature (Table 5). Further research is required to resolve this matter, starting with the cataloguing and description of all the sub-circular anomalies to ascertain if there are groupings in terms of size and the strength of the magnetic field, which may help to interpret these anomalies. Whether pits, hearths or something 


\begin{tabular}{lcrr}
\hline Anomaly & $\min (\mathrm{nT})$ & $\max (\mathrm{nT})$ & range $(\mathrm{nT})$ \\
\hline 5 & -6.06 & 17.62 & 23.68 \\
11 & -5.04 & 19.19 & 24.23 \\
4 & -5.12 & 23.94 & 29.06 \\
8 & -8.59 & 21.07 & 29.66 \\
6 & -4.8 & 25.64 & 30.44 \\
12 & -6.01 & 24.58 & 30.59 \\
2 & -6.17 & 24.59 & 30.76 \\
3 & -8.32 & 26.3 & 34.62 \\
10 & -6.65 & 32.9 & 39.55 \\
7 & -7.04 & 33.02 & 40.06 \\
9 & -8.32 & 38.91 & 47.23 \\
1 & -10.4 & 55.14 & 65.54 \\
\hline
\end{tabular}

Table 5: Minimum, maximum and the range of nanotesla values for subcircular anomalies in the 'quiet area' at Verulamium.

else entirely, the question of the nature of the settlement in the 'quiet' area remains a priority.

Fig. 13D shows the ' 1955 ' ditch running across the lower-left corner of the plot. A rectangular anomaly is indicated with an arrow. This anomaly, which was $c .4 .8 \times 2.8 \mathrm{~m}$ had a range of $-6.1-23.8 \mathrm{nT}$. One suggestion was that this represented a cellar, and to investigate further GPR, resistance and magnetic susceptibility surveys were carried out over this area (Fig. 14). These did not detect a stone wall surrounding the anomaly and therefore we remain unsure as to its interpretation. The linear negative anomaly that runs across Fig. 13D and along the SW edge of the anomaly was a ditch still visible on the surface of the field. Further investigation is needed.

\section{Mapping the fire?}

The overall plot of the magnetometry survey (Fig. 4) clearly showed some areas with strong magnetic fields and some with weaker magnetic fields and quiet areas. The buildings discussed above also revealed that in parts of the town they could be detected easily, whereas in other parts of the town they were harder to identify. Why? Clearly, those buildings that were easy to detect had foundations that went through more magnetic material. In some cases, this could be tile floors or hypocaust debris. Alternatively it may, in part, be the result of the Antonine fire of $c$. AD 155 (Niblett \& Thompson 2005, p. 157 and Fig. 4.72). Evidence for the fire has been found on a number of sites that match well with those areas where stone structures have been clearly detected (Fig. 15).

One approach to understanding the visibility or otherwise of the stone 


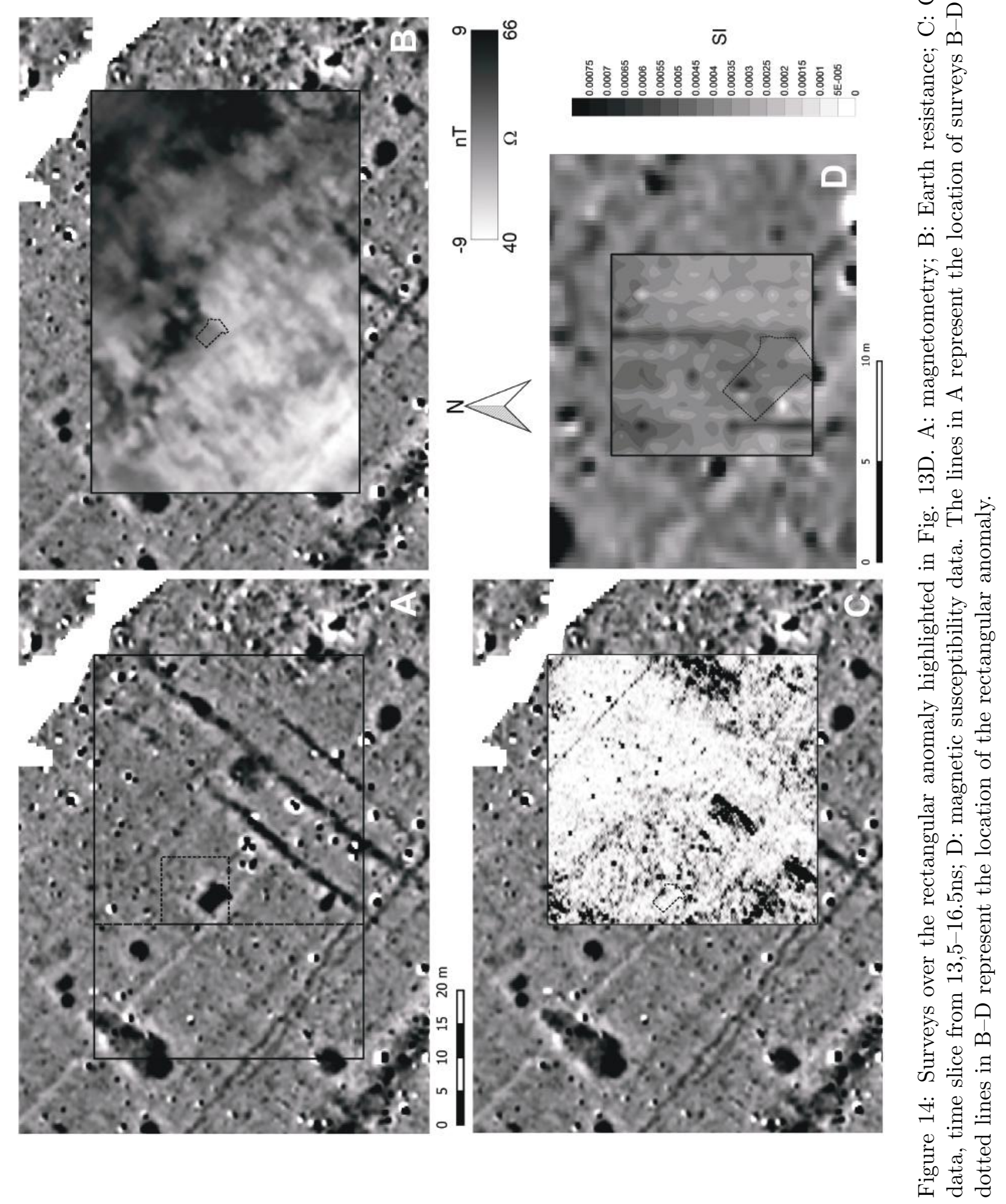




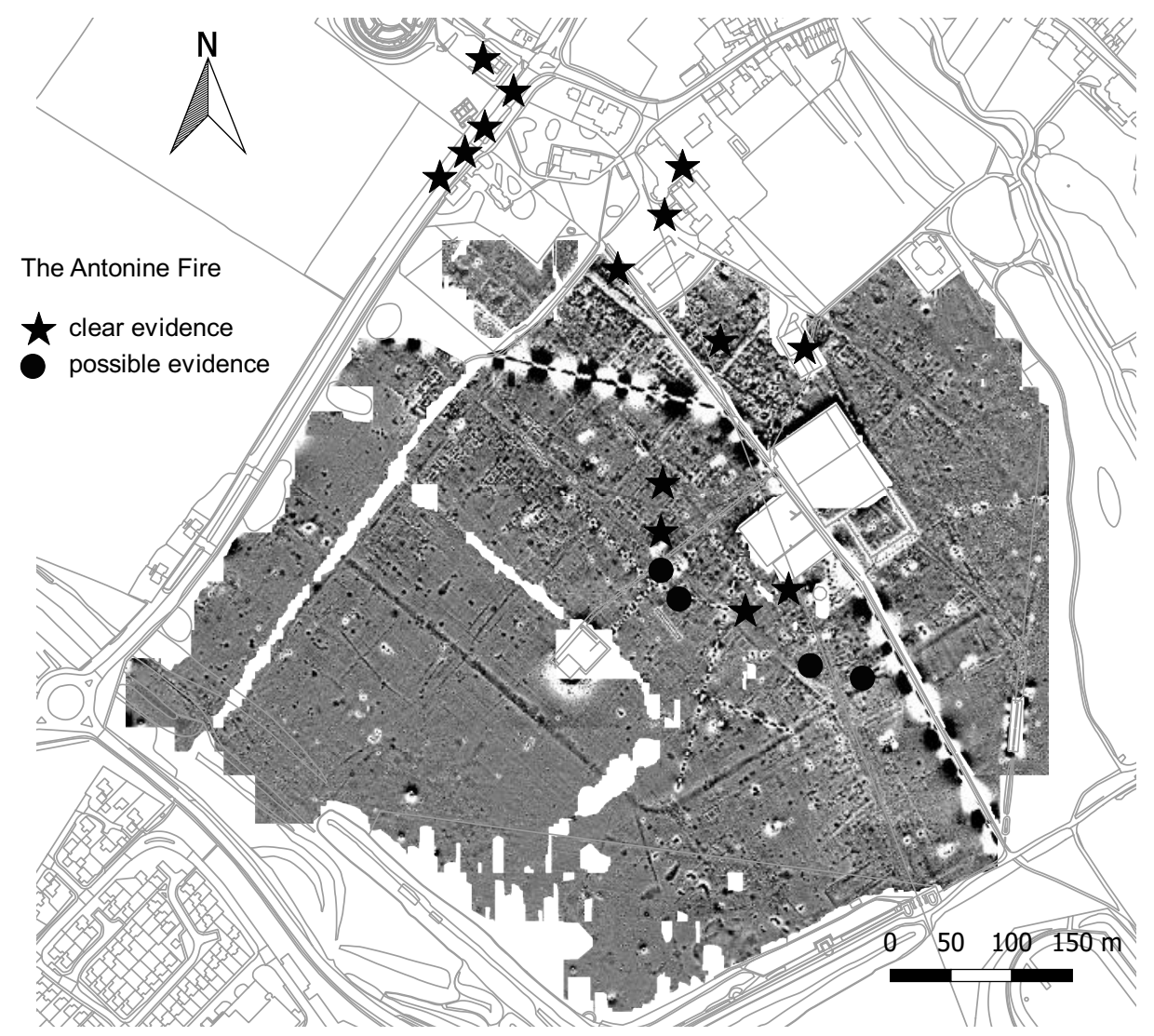

Figure 15: Locations of the excavated evidence for the Antonine fire overlain on the magnetometry results. Fire locations from Niblett (1983-1986). Base mapping: (c) Crown Copyright/database right 2015. An Ordnance Survey/EDINA supplied service. 


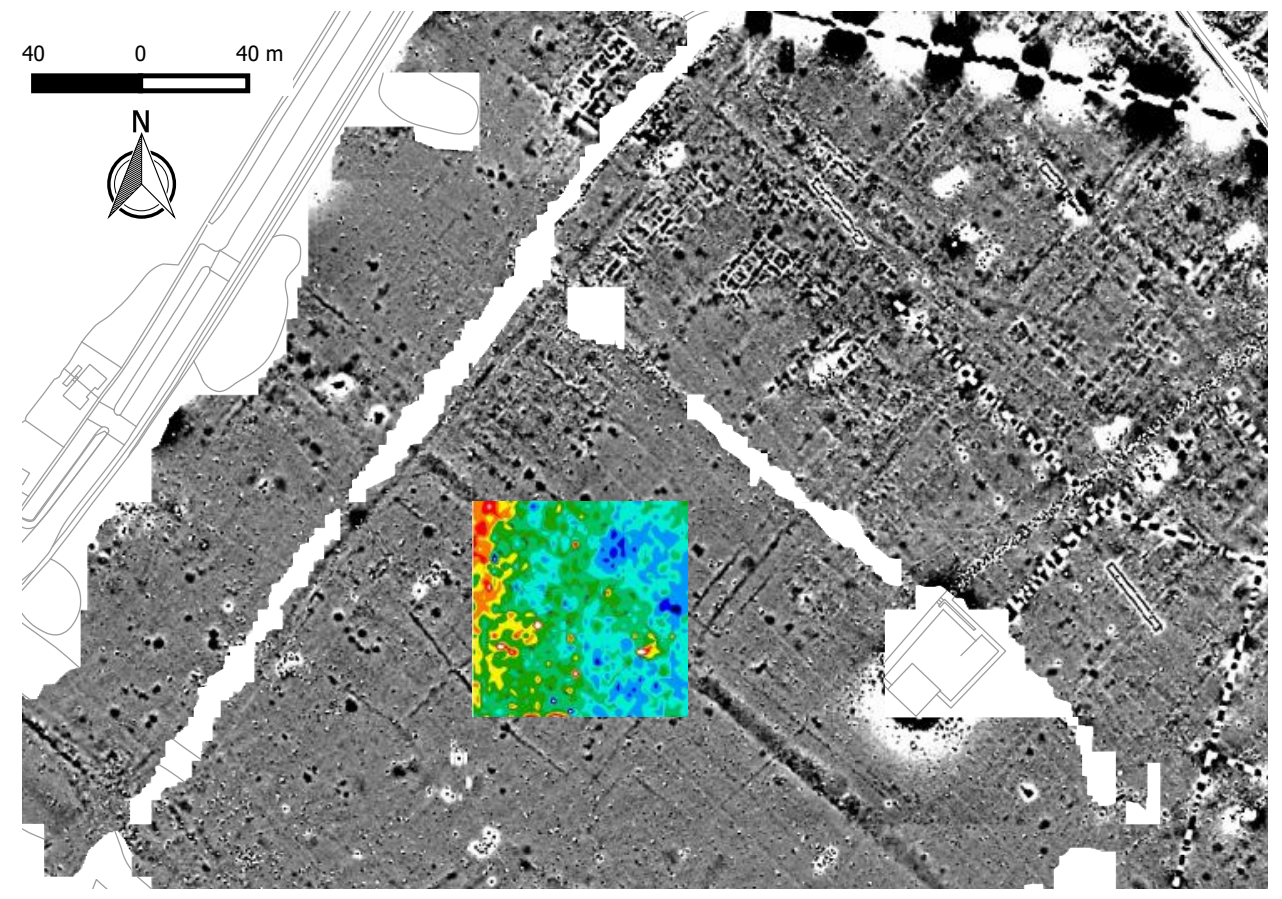

Figure 16: The magnetic susceptibility survey overlain on the base mapping and the magnetometry survey. Magnetic susceptibility plot courtesy of Rinita Dalan. Base mapping: (c) Crown Copyright/database right 2015. An Ordnance Survey/EDINA supplied service. 
structures would be to conduct a magnetic susceptibility survey, which is often an excellent method for determining areas of burning. Rinita Dalan and the course participants undertook a survey on an area $80 \times 80 \mathrm{~m}$ at $2 \mathrm{~m}$ intervals using a Bartington MS2 meter with an MS2D loop (see above). Fig. 16 shows the results of this survey. The band of values plotted green that follows the line of the '1955' ditch gave some confidence that the topsoil retains some significant patterning. The highest values were, however, to the west closer to the road. In general, especially to the north of that Insula, the structures closer to the road showed more clearly in the magnetometry data. Although the layers of burning are below the levels measured by the MS2D loop, the redeposition of sediment by the digging of foundation trenches, pits and the like followed by subsequent ploughing, were likely to lead to magnetic enhancement of the soil nearer to the surface.

This initial result suggests that expanding the magnetic susceptibility survey over the whole of Verulamium may well be a profitable exercise and could help to map the Antonine fire.

\section{Conclusions}

In conclusion, we wish to briefly discuss the outcomes and the future of the work discussed here.

One successful outcome of the project was the creation of a team of amateur geophysicists who have continued to undertake surveys across Hertfordshire and nearby counties. This aspect of the project will be discussed elsewhere, but it should be noted that in August 2015, the group completed a further 18 days of survey work at Verulamium, mainly extending the magnetometry survey but also undertaking more extensive GPR surveys. An additional two seasons of work will be needed to complete the magnetometry survey of the inside of the town.

Secondly, the survey at Verulamium has clearly added a great deal of information to our knowledge of the town. Much remains to be done, however. As noted above, the magnetometry survey of the north-western half of the town began in August 2015, ${ }^{3}$ supplemented by more limited GPR survey (Lockyear 2015). The GPR surveys in the Park are also being extended. It is desirable to undertake a large scale magnetic susceptibility survey, and resistance surveys using a cart-based system might also add useful data.

The digitisation of every geophysical anomaly located within the project GIS will also be a mammoth task, as will relating those anomalies to excavation plans, aerial photographs and other data about the town. Comparison of the geophysical survey results with the Urban Archaeological Database (UAD) maintained by St Albans City and District Council shows that some

\footnotetext{
${ }^{3}$ We are immensely grateful to the Earl of Verulam for facilitating our access to the Estate during August.
} 
of the monuments are not quite in the right place. This is unsurprising given that early surveys were tied to impermanent datum points while the current survey was undertaken using high-accuracy dGPS and Total Stations. As a result we will be able to help correct and expand the UAD.

Our initial examination of the results of the surveys presented here have, however, suggested the following. Firstly, large town houses continue to be concentrated within the line of the '1955' ditch, whereas more modest dwellings were to be found either close to, or beyond the ditch. Secondly, the southern area, where many of these more modest dwellings were detected, appears to be an industrial area which may have been incorporated into the town prior to its final expansion to the line of the town walls in the third century. Thirdly, the western 'quiet' area remains problematic. We have been unable to detect structures with stone foundations, but have found a number of linear and sub-circular anomalies representing ditches, pits and possibly hearths. There are at least three possible explanations. 1) the area was indeed largely devoid of structures; 2) the visibility of the structures was, in part, determined by the extent of the Antonine fire which may not have affected this area; or 3) ploughing, combined with the slope running towards the river, may have destroyed all but the deepest cut features.

Once we have completed the survey of the entire town, the results will need to be examined in the light of broader questions about the towns of Roman Britain. The Wroxeter survey challenged the idea that it was a 'garden city', but at present the evidence from Verulamium seems more in keeping with that model. We are already able to see 'zones' within the town, but can we use this evidence to detect neighborhoods, building on the work of Smith (2010)? We can already see a central zone (the basilica-forum complex, theatre and temple), an area dominated by large houses, a more industrial zone, and a quiet, possibly agricultural zone to the west of the ' 1955 ' ditch. Integrating the extensive excavated evidence, including the test-pits excavated in 2000 by Oxford Archaeology (Niblett \& Thompson 2005 , event 635), crop mark data and geophysics to create a comprehensive image of the city is the challenge that lies ahead.

Some questions, however, will never be answered by geophysics alone. For example, what date is the ditch that appears to join the SW corner the '1955' ditch? What date is the enclosure near the southern edge of the town? Are the large positive anomalies in the quiet western half of the town evidence of buildings the magnetometer could not detect, or was this area largely devoid of structures? These questions can only be answered by carefully targeted excavation.

The work at Verulamium has achieved much so far, but there is a great deal more that can be done and the next few years will be an exciting time for those involved in the archaeology of the town. 


\section{Acknowledgements}

The authors would like to thank, first and foremost, the project team for their boundless enthusiasm and dedication, especially Jim West (CVAHS), Mike Smith (WHS), Pauline Hey (LBALHS), John Dent (SAHAAS), Clare Lewis (WAS), Jon Wimhurst (WAS), Stuart Henderson (SAHAAS), Roger Miles (SAHAAS), David Minty (WAS), Jean Savigar (BDAS/BAS), Jean Bluck (BAS), Ruth Halliwell (WAS) and Ralph Potter (WEAG). The project was funded by the AHRC (Grant Ref AH/K007602/1) which facilitated the purchase of the magnetometer which will continue to be used by the team over the coming years. The geophysics course was funded as part of the grant, but additional support was given by Verulamium Museum, Bartington Instruments, DW Consulting and Archaeology South-East. Andrew Bevan, Jarrod Burks, Lawrence Conyers, Rinita Dalan and David Wilbourn acted as instructors. John Cook from Archaeology South-East provided much needed survey support during the course, and the West Essex Archaeology Group kindly loaned us their TRCIA resistance meter when the Welywn Archaeological Society's machine developed a fault. The staff at Verulamium Museum are to be thanked for providing storage space during the survey, and putting up with our muddy boots! David Thorold, in particular, has continued to be extremely supportive. Simon West, the St Albans District Archaeologist, has been equally supportive and the SADC also provided the GIS data. Ralph Potter has kindly carried out GPR surveys using his system. Sarah Poppy from English Heritage (now Historic England) has helpfully provided the necessary licences. Training in the use of the Foerster system was provided by Thomas Himmler and Pat Johnson. We would also like to thank Verulamium Museum for hosting a preliminary meeting to discuss the results, and to thank those who attended: David Thorold, Simon West, Neil Linford, Rosalind Niblett and Isobel Thompson. Lastly, I would like to thank David Wigg-Wolf and the Römisch-Germanische Kommission for their hospitality whilst we were writing this paper.

\section{References}

Aitkin, M. J. 1960. 'Verulamium 1959: the magnetic survey.' Antiquity 40: $21-24$.

Aitkin, M. J. 1961. 'The magnetic survey.' Antiquity 41: 83-85.

Anthony, I. E. 1968. 'Excavations in Verulam Hills Field, St Albans, 1963-4.' Hertfordshire Archaeology 1: 9-50.

Bescoby, D., W. Bowden \& P. N. Chroston 2009. 'Magnetic survey at Venta Icenorum, Caistor St Edmund: Survey strategies and initial results.' Archaeological Prospection 16(4): 287-91. 
Bowden, W. 2013. 'The urban plan of Venta Icenorum and its relationship with the Boudican revolt.' Britannia 44: 145-69.

Bowden, W. \& D. Bescoby 2008. 'The plan of Venta Icenorum (Caistorby-Norwich): interpreting a new geophysical survey.' Journal of Roman Archaeology 21: 324-34.

Brien, M. 2010. Verulamium Park, St Albans. Geophysical Survey 12000103. Report prepared by Met Geo Environmental for St Albans City and District Council.

Buteux, S., V. Gaffney, R. White \& M. van Leusen 2000. 'Wroxeter Hinterland Project and geophysical survey at Wroxeter.' Archaeological Prospection 7: 69-80.

Cole, M. 1994. Verulamium, St Albans. Report on Geophysical Survey 1994. Ancient Monuments Laboratory Report 2/94.

Cosh, S. \& D. S. Neal 2015. 'The dating of building 2, Insula XXVII, at Verulamium: a reassessment.' The Antiquaries Journal 95: 65-90.

Creighton, J. D. in press. Silchester: Changing visions of a Roman town. Britannia Monograph No. 28. Roman Society, London.

Dabas, M., A. Hesse \& J. Tabbagh 2000. 'Experimental resistivity survey at Wroxeter archaeological site with a fast and light recording device.' Archaeological Prospection 7: 107-18.

Faulkner, N. 2000. The Decline and Fall of Roman Britain. Tempus, Stroud.

Frere, S. S. 1972. Verulamium Excavations Vol. I. Research Reports of the Society of Antiquaries of London 28. Society of Anitquaries of London, Oxford.

Frere, S. S. 1983. Verulamium Excavations Vol. II. Research Reports of the Society of Antiquaries of London 39. Society of Antiquaries of London, London.

Frere, S. S. 1984. Verulamium Excavations Vol. III. Oxford University Committee for Archaeology Monograph No. I. Oxford University Committee for Archaeology, Oxford.

Frere, S. S. \& P. WitTs 2011. 'The saga of Verulamium building XXVII 2.' Britannia 42: 212-26.

Fulford, M. 2015. 'The towns of south-east England.' In M. Fulford \& N. Holbrook (eds.), The Towns of Roman Britain. The contribution of 
commercial archaeology since 1990, Britannia Monograph Series No. 27, pp. 59-89. Society for the Promotion of Roman Studies, London.

Gaffney, C. \& J. Gator 2003. Revealing the Buried Past. Geophysics for archaeologists. Tempus, Stroud.

Gaffney, C. F., J. A. Gater, P. Linford, V. L. Gaffney \& R. White 2000. 'Large-scale systematic fluxgate gradiometry at the Roman city of Wroxeter.' Archaeological Prospection 7: 81-99.

Kenyon, K. M. 1935. 'The Roman theatre at Verulamium, St. Albans.' Archaeologia 84: 213-61.

Linford, N. T. 2000. Verulamium, St Albans, Herts. Report on Geophysical Survey, January 2000. Ancient Monuments Laboratory Report 64/2000.

Lockyear, K. 2012. 'Dating coins, dating with coins.' Oxford Journal of Archaeology 31(2): 191-211.

LOCKYeAR, K. 2015. 'New surveys at Verulamium.' ISAP News 44: 6-8.

Lowther, A. W. G. 1937. 'Report on excavations at Verulamium in 1934.' The Antiquaries Journal 17(1): 28-55.

Millett, M. 1990. The Romanization of Britain. Cambridge University Press, Cambridge.

Neal, D. S. 2003. 'Building 2, Insula XXVII from Verulamium: A reinterpretation of the evidence.' In P. Wilson (ed.), The Archaeology of Roman Towns, pp. 193-202. Oxbow Books, Oxford.

Niblett, R. 1983-1986. 'Evidence for the Antonine fire at Verulamium from the Wheelers' excavations.' Hertfordshire Archaeology 9: 29-78.

Niblett, R. 2001. Verulamium. The Roman City of St Albans. Tempus, Stroud.

Niblett, R., W. Manning \& C. Saunders 2006. 'Verulamium: Excavations within the Roman town 1986-88.' Britannia 37: 53-188.

Niblett, R. \& I. Thompson 2005. Alban's Buried Towns. An assessment of St Albans' archaeology up to AD 1600. Oxbow Books, Oxford.

Nishimura, Y. \& D. Goodman 2000. 'Ground-penetrating radar survey at Wroxeter.' Archaeological Prospection .

Powlesland, D. 2009. 'Why bother? large scale geomagnetic survey and the quest for real archaeology.' In S. Campana \& S. Piro (eds.), Seeing the Unseen: Geophysics and Landscape Archaeology, pp. 167-82. CRC Press, Leiden. 
Powlesland, D. 2015. 'Reflections upon 30+ years of computing and field archaeology in the Vale of Pickering, North Yorkshire UK.' In A. Traviglia (ed.), Across Space and Time. Papers from the 41st Conference on Computer Applications and Quantitative Methods in Archaeology, Perth, 25-28 March 2013, pp. 169-91. Amsterdam University Press, Amsterdam.

Reece, R. 1980. 'Religion, coins and temples.' In W. Rodwell (ed.), Temples, Churches and Religion: Recent Research in Roman Britain, pp. 115128. British Archaeological Reports British Series 77, Oxford.

Smith, M. E. 2010. 'The archaeological study of neighborhoods and districts in ancient cities.' Journal of Anthropological Archaeology 29: 137-54.

Stead, I. M. \& V. Rigby 1986. Baldock. The Excavation of a Roman and pre-Roman Settlement 1968-72. The Society of the Promotion of Roman Studies, London.

Stead, I. M. \& V. RigBy (eds.) 1989. Verulamium: the King Harry Lane Site. English Heritage Archaeological Report No. 12. English Heritage in association with British Museum Publications, London.

Thorold, D. 2015. Roman Verulamium. St Albans Museums, St Albans.

Tyers, P. 1996. Roman Pottery in Britain. Batsford, London.

Walker, A. R. 2000. 'Multiplexed resistivity survey at the Roman town of Wroxeter.' Archaeological Prospection 7: 119-32.

Webster, G. \& B. Stanley 1962-1963. 'Viroconium: a study of problems.' Transactions of the Shropshire Archaeological Society 57(2): 11227.

Wessex Archaeology 2009. Caerwent Roman Town, Monmouthshire, South Wales: Archaeological Evaluation and Assessment of Results. Available from http://www.wessexarch.co.uk/files/68736_ Caerwent\%20Monmouthshire.pdf. Last accessed 2/11/2015.

West, S. 2015. "Out of town and on the edge?': evaluating recent evidence for Romanisation within the Verulamium region.' In K. Lockyear (ed.), Archaeology in Hertfordshire: Recent Research. A festschrift for Tony Rook, pp. 197-221. University of Hertfordshire Press, Hatfield.

Wheeler, R. \& T. Wheeler 1936. Verulamium. A Belgic and two Roman Cities. Research Reports of the Society of Antiquaries of London 11. Society of Antiquaries of London, Oxford. 
White, R. H., C. Gaffney \& V. L. Gaffney 2013. Wroxeter, the Cornovii and the Urban Process: Volume 2: Characterizing the City. Final Report of the Wroxeter Hinterland Project, 1994-1997. Archaeopress Archaeology, Oxford. 